\title{
Natural Disasters and Economic Growth: The Mitigating Role of Microfinance Institutions
}

\author{
John Sseruyange ${ }^{1, *}$ and Jeroen Klomp ${ }^{2,3}$ \\ 1 School of Economics, Makerere University, 10218 Kampala, Uganda \\ 2 Development Economics Group, Wageningen University \& Research, 6700 EW Wageningen, The Netherlands; \\ jeroen.klomp@wur.nl \\ 3 Faculty of Military Sciences, Netherlands Defence Academy, 4800 PA Breda, The Netherlands \\ * Correspondence: johnsseruyange@gmail.com
}

Citation: Sseruyange, J.; Klomp, J. Natural Disasters and Economic Growth: The Mitigating Role of Microfinance Institutions. Sustainability 2021, 13, 5055. https:// doi.org/10.3390/su13095055

Academic Editors:

Maria Del Mar Miralles-Quirós and José Luis Miralles-Quirós

Received: 17 March 2021

Accepted: 26 April 2021

Published: 30 April 2021

Publisher's Note: MDPI stays neutral with regard to jurisdictional claims in published maps and institutional affiliations.

Copyright: (c) 2021 by the authors. Licensee MDPI, Basel, Switzerland. This article is an open access article distributed under the terms and conditions of the Creative Commons Attribution (CC BY) license (https:// creativecommons.org/licenses/by/ $4.0 /)$.

\begin{abstract}
In this study, we explore whether microfinance institutions (MFIs) can mitigate the adverse macroeconomic consequences of natural disasters. The provision of capital immediately following a natural event is recognized as one of the necessary conditions for a fast economic recovery. However, one concern is that a large majority of natural disasters occur in developing countries where households and the private sector have only limited access to the formal banking system. As an alternative, MFIs may fill up this gap in providing liquidity in the form of microcredit. The existing evidence on how MFIs respond to disaster effects is foremost based on case and micro-level evidence. In turn, the focus of this study is more on the macro impact of MFI activities after a natural disaster. Based on the finding obtained from an OLS-FE model using an unbalanced panel considering more than 80 developing countries and emerging economies, we can conclude that natural disasters harm macroeconomic performance primarily through their effect on the agricultural sector. However, access to lending facilities from MFIs mitigates a large part of this negative effect. Moreover, the extent to which MFIs are able to mitigate these effects depends to a great extent on their nature, i.e., their organizational structure, profitability, legal status, age, and the number of clients they serve.
\end{abstract}

Keywords: natural disasters; microfinance; economic growth

\section{Introduction}

This study deals with the question of whether participating in microfinance activities in the aftermath of a natural disaster can mitigate the adverse macroeconomic consequences in the short run. Since the 1970s, the frequency and severity of natural disasters have risen dramatically. For example, a devastating earthquake hit Haiti in 2010, causing over 250,000 deaths. In November 2013, Typhoon Haiyan ravished parts of Taiwan, China, Vietnam, and the Philippines, causing several landfalls and mudslides that resulted in 6300 deaths, nearly 17 million people were affected, and the estimated damage exceeded USD 9.7 billion. These are only two examples of extreme events caused by forces of nature that have occurred in the last years. More worrying is that the situation may become even worse in the coming decades since natural disasters are often linked to the ongoing process of climate change [1].

Despite the fact that a lot of mitigation efforts have been undertaken by many governments and international organizations around the globe over the last decade, the problem remains rather prevalent, especially in developing countries. In particular, more than 80 percent of the vulnerable population identified lives in Africa, Asia, or Oceania [2]. This prevalent problem in these countries is explained by a combination of three features that are most present in developing countries: a higher physical exposure in many areas to climatic shocks, a higher economic vulnerability to climate events due to heavier reliance on the agricultural sector, and a lower adaptive capacity [3-6]. 
There is a general consensus in the empirical literature that natural disasters have a negative effect on the short-run macroeconomic performance of a country [3,4,7-15]. This adverse effect is mainly explained by the large-scale destruction of the productive capital stock. Based on this insight, one obvious key mitigation strategy to ease the macroeconomic impact is the immediate provision of capital in the aftermath of a disaster. The prompt provision of liquidity in the form of aid, grants, or loans following a disaster to the affected areas makes it possible for firms to reinvest and for households to have smooth consumption. Besides, replacement investments typically embed better or more advanced technologies than the destroyed capital. This, in turn, will improve the long-run economic growth perspective of a country $[4,14]$. Thus, successful recovery after a natural disaster starts with the possibility to reinvest, which in turn is indisputably related to access to credit. This idea was empirically confirmed by Melecky and Raddatz [16], Von Peter et al. [17], and McDermott et al. [18], who found the degree of financial development to be an important factor in addressing the macroeconomic consequences of a disaster. This is done by lifting the financial constraint faced by the private sector in the aftermath. Already in the predisaster period, developed financial markets serve a crucial role by creating opportunities for investing in precautionary measures or infrastructure that can withstand disaster effects. However, there are still two major gaps remaining in the literature that this paper tries to fill.

First, unfortunately, a relevant share of the affected population in developing countries does not have enough savings after a natural disaster when the latter destroys their few available resources. At the same time, they also have only limited access to formal credit markets, as they are missing or incomplete in many rural areas in developing countries [19], or simply because households lack the collateral to obtain a loan in the aftermath. Nevertheless, it is exactly these particular countries that are the most exposed and vulnerable to large-scale natural disasters. According to figures reported by EM-DAT, at least a quarter of the least developed nations have been hit by between two to eight major disasters per year in the last two decades [2]. As a result, many households are forced to dispose of their productive assets after a natural disaster to finance consumption. This will jeopardize future growth prospects of households or, even worse, trap them in poverty.

One alternative to formal finance is microfinance. Microfinance has become one of the most important intermediaries in the financial sector in developing countries and is regarded as one of the most successful poverty reduction policies. Many of their borrowers are socially excluded and lack access to conventional credit systems. Microfinance helps poor households in the sense that once they obtain credit from a microfinance institution, they will be able not only to enhance their income and consumption levels, but also to improve their tolerance against idiosyncratic income shocks through the improved access to credit [20-22].

There exists vast literature on the potential micro effects of credit constraints, arguing that access to MFI credit can ease the adverse economic effects caused by a natural disaster [23-26]. However, the evidence so far is mainly based on micro-level studies of a single event. Using these case studies makes it difficult to draw general conclusions since, based on their physical magnitude, natural disasters differ in their economic effect, the activities employed by MFIs are likely to vary between MFIs, and the socio-economic context of the disaster location differs.

The second gap we try to fill is related to the non-uniform relation between natural disasters and sector-specific economic development and the potential mediating effect of MFIs on this outcome. As already demonstrated by Loayza et al. [4], the economic effects of natural disasters cannot be framed within one-sector growth models using an aggregate production function. For example, there is no reason to assume that natural disasters would affect the various economic sectors present within a country to the same extent or even in the same direction. Droughts, for example, exhaust the availability of water as an input to agriculture, whereas earthquakes are especially a threat to the capitalintensive industrial sector. Hence, aggregate growth analyses mask and conflate such 
differences, which could lead to the puzzling conclusion of nil or ambiguous effects of natural disasters on overall economic development $[4,27]$. Based on this latter observation, the response of MFIs to disaster effects might also differ between economic sectors that are being affected. For example, MFIs may be reluctant to respond to agriculturalists' demands following a disaster due to the high expected default rate associated with farmers after a disaster. Contrariwise, if industries and services have taken appropriate precautionary measures that lower their vulnerability or the extent of damages, their chance of defaulting is reduced $[28,29]$.

Our main contribution to the existing literature is twofold. First, we examine whether the relationship between sector-specific economic development and natural disasters relies on access to the lending facilities provided by MFIs. Second, we try to relate the observed differences across sectors to the nature of particular MFIs being active in a country. Some MFIs operate as regulated banks and serve a large number of poor households, whereas others operate more like non-profit organizations benefiting only a small number of clients [30,31]. More generally, this study fits into the broad strand of the economic growth literature dealing with sustainable economic development; see [32-34]

Based on the discussion above, we formulated our hypotheses that will be tested in the empirical section.

Hypothesis 1 (H1). Participating in MFI borrowing activities mitigates the negative impact of natural disasters on short-run economic performance.

Hypothesis 2 (H2). The mitigating impact of MFI activities after a natural disaster differs among different types of MFIs.

Hypothesis 3 (H3). The mitigating impact of MFI activities after a natural disaster differs among economic sectors present in a developing country.

For the purpose of the study, we use a panel model including data on natural disasters extracted from the GAME dataset provided by CESifo for the period between 1995 and 2010. We include over 80 low and middle-income countries. The dataset contains detailed information about the exogenous exposure of a specific country to a natural hazard. Moreover, the data used on access to MFIs is based on the number of borrowers provided by Mix Market. This dataset includes detailed balance sheet information for more than 1200 MFIs in over 100 countries. Finally, data on sector-specific economic performance (i.e., agriculture, industry, and the service sector) are taken from the World Development Indicators [35].

Our main findings suggest first that natural disasters put downward pressure on the performance of the agricultural sector only. However, part of the disaster shock caused by a natural disaster can be mitigated through improved access to the lending facilities provided by MFIs. To be more specific, access to MFIs mitigates about one-third of the initial negative effect. The extent to which MFIs can mitigate these effects differs between institutions and largely depends on their nature, i.e., their organizational structure, profitability, legal status, age, and the number of clients they serve.

The remainder of the paper is structured as follows. Section 2 reviews and summarizes the relevant literature related to our research question. Section 3 describes the data and methodology used. Section 4 shows our estimation results regarding whether microfinance institutions are able to mitigate the macroeconomic consequences of disasters, and the final section offers the conclusions.

\section{Literature Review}

Microfinance institutions (MFIs) have become one of the most important intermediaries in the financial sector in developing countries. Their growth parameters are outstanding, both in the number of entities and total assets. According to data reported by Mix Market, the number of MFIs has increased by more than 22 percent annually in the last 
decade, whereas the amount of assets increased by about 30 percent yearly over the same period [36].

During this period of rapid growth, the business model used by many MFIs has changed significantly. In the beginning, their main focus in social matters appeared to be the key attraction. Nowadays, many MFIs operate more like commercial banks and are assessed based on their efficiency and profitability. One thing that actually has not changed is that many of their borrowers are still socially excluded and lack access to conventional credit systems. The lack of collateral, high administrative costs relative to the loan value, and incomplete information regarding borrower quality make traditional lending infeasible for most clients demanding microloans. Special arrangements such as group lending, frequent repayments (e.g., weekly loan payments), and other mechanisms help MFIs to overcome these information problems and allow for profitable lending to these clients $[14,37,38]$.

In the remainder of this section, we briefly review the existing case study evidence about the question of whether microfinance could enhance economic recovery after a natural disaster. First, Shoji [25] found that MFIs in Bangladesh have used a contingent repayment system (rescheduling of weekly savings and installments) to reduce the repayment pressure on the victims after the 1998 floods. The reduced repayment pressure on the victims played a significant role in the recovery process since it worked as a kind of safety net. For instance, the study revealed that because of this contingent repayment system, the probability of people skipping meals during a shock was reduced by more than five percent. More so, Berg and Schrader [39] combined client information from an Ecuadorian microfinance institution together with geophysical data on natural disasters, and their main findings demonstrated that microcredit helped the victims of Tungurahua volcanic eruption through loan provisions, especially to repeating borrowers. However, their results from this natural experiment also showed that although credit demand increases due to volcanic activity, access to credit is restricted. Improved MFI-borrower relationships lower these lending restrictions again.

Likewise, Kumar and Newport [40] argued that microfinance should be recognized as one of the key disaster risk management strategies designed to help disaster victims, especially poor households. According to Kumar and Newport [40], MFIs provide a range of financial services (informal and flexible financial instruments) to the poor for disaster mitigation not only at the community level but also within the informal economy. This is supported by Pantoja [41], who maintained that poor households mainly rely on informal though market-based social and financial services. Pantoja [41] observed that after a disaster, affected areas tend to experience a significant reduction in housing, health, and education provisions; an increase in unemployment; a temporary shortage of food; plus interruptions in agricultural, industrial, and service provisions for which the social and financial services provided by MFIs try to mitigate. However, he further pointed out that the achievements of an MFI can be erased by a single disaster or undermined by repeated disasters, causing their borrowers to become vulnerable. Consequently, the operational and financial sustainability of such MFIs can be compromised, especially if the frequency of the disasters is high (see also Klomp [31]).

Moreover, Becchetti and Castriota [26] evaluated the effectiveness of microfinance as a recovery tool after the tsunami in 2004 hitting Southeast Asia by testing the impact of an equity injection from foreign donors, which recapitalized a Sri Lankan MFI and allowed it to refinance borrowers seriously damaged by the calamity. They found that loans obtained from the MFI after the catastrophic event had a positive and significant effect on the change in real income and in weekly worked hours and that the impact on performance variables was significantly stronger for damaged than non-damaged borrowers.

Furthermore, Khandker [24] and Del Ninno et al. [42] studied the coping strategies adopted by rural households during the 1998 flood in Bangladesh and assessed their impact on welfare. These studies concluded that the presence of microcredit programs increased the demand for loans. It turned out that the consumption and asset holding of households 
that participated in the borrowing program increased. Hoque and Itohara [43] concluded, also using data from rural Bangladesh, that microcredit programs may increase the abilities of participating households to cope with the economic consequences of floods and other natural disasters.

\section{Data and Methodology}

\subsection{Data}

Our aim was to estimate the impact of natural disasters on economic development and to see to what extent this effect relies on access to MFI lending facilities in a particular country. One of the main challenges in the literature about the macroeconomic impacts of natural disasters is the identification strategy of these events, as they are the product of hazard, exposure, and vulnerability $[13,15]$. Most scholars agree that a large part of the hazard to a natural event is beyond government control or can be affected by the behavior of a single person (exogenous). In contrast, the exposure and vulnerability part of a disaster event, in terms of the number of people affected or physical damage created, depends to some extent on the socio-economic situation or government choices made [44]. For instance, the total damage created by a disaster is often positively related to the level of income, whereas the number of people affected is negatively affected by the level of income.

To estimate the impact of natural disasters, it is therefore important to separate the exposure and vulnerability element from the natural disaster impact and focus exclusively on the hazard part. Hence, we should use detailed information about the physical strength of natural disasters-earthquakes, storms, floods, droughts. The data on the physical magnitude of natural disasters and their impact is documented in the GAME dataset collected by CESifo.

First, a flood is recognized in a particular month when precipitation is more than five times the monthly average or when in a specific month rainfall is more than half of the long-run yearly average rainfall. Second, a drought is recorded in a country-year when at least three subsequent months have rainfall below 50 percent of the long-run average monthly mean, or if at least five months within a year have rainfall below 50 percent of the long-run monthly mean. Third, an earthquake is considered when the magnitude of the seismic event is above four on the Richter scale. Below this threshold, it is almost not felt by people and does not cause any damage. Finally, a storm should at least be at score 1 on the Saffir-Simpson Hurricane Wind Scale index, which is equivalent to a wind speed of about $119 \mathrm{~km} / \mathrm{h}$. In total, there are more than 2000 natural disasters recognized in our period of analysis. Floods are the most common type of natural disaster. More than half of the natural disasters are recognized in this category. In turn, less than five percent of the natural disasters are classified as droughts.

To determine the impact of natural disasters on economic development, we constructed for each country-year a disaster count variable that took the timing of a disaster in the course of a year into account. This allowed catastrophes happening at the beginning of the year to have a different impact than those that happened near the end of the year.

$$
\text { disaster }_{i t}= \begin{cases}\frac{\sum\left(\left(12-M_{k t}\right) / 12\right)+\sum\left(M_{n t-1} / 12\right)}{\rho_{i}} & \text { (post)disasteryear } \\ 0 & \text { otherwise }\end{cases}
$$

Since the contemporaneous impact of a disaster within one year was considered, our annual disaster measure was calculated as the weighted sum of disasters $k$ that happened in the current year $t$ and the disasters $n$ that occurred in the previous year $t-1$. We weighted this sum by the month $M$ when the respective disaster happened. That is, we assigned the value $(12-M) / 12$ to a disaster year and $M / 12$ to the post-disaster year. In all other years, its value was set to zero. Using a count measure put equal weight on the disaster events. This had the advantage of reducing the influence of outlier events at the upper end of the disaster distribution. Besides, a country that is hit more than once by a major disaster in the same year will suffer more in economic terms than a country that is hit by only a 
single incident. We normalized the number of disaster events by the land area of a country $i$ in $1000 \mathrm{~km}^{2}$, represented by $\rho_{i}$. Obviously, larger countries have a higher probability of experiencing a natural event. When, for instance, Argentina is hit by a hurricane, the consequences for the economy as a whole are likely to be smaller than when Haiti is hit by the same hurricane. Especially small island states are extremely vulnerable because of the higher frequency of natural disasters that have a disproportionately large impact on their economies [7,11,44-46].

The data on MFIs was taken from Mix Market, a global web-based microfinance information platform (www.mixmarket.org (accessed on 12 September 2012)). The Mix Market dataset includes information from more than 1200 MFIs, controlling a total asset of over USD 100 billion and serve more than 60 million borrowers. The financial data includes balance sheets, income statements, and detailed portfolio report information. Mix Market reviews the data against audits and ratings and uses trend data and industry benchmarks for accuracy. The data is further reviewed against more than 150 business rules to identify potential reporting errors. This database has been widely used in the microfinance literature [22,47-52].

Using MFI data, two types of sample selection problems might occur. The first regards the countries covered. In the main models, we included more than 80 countries from all parts of the world. In particular, our sample includes almost all countries classified as a developing country or emerging economy by the UNDP. This wide coverage reduces the sample selection concerns especially related to natural disasters. Second, reporting to Mix Market by MFIs is done on a voluntary basis, which may, at least potentially, have consequences for the reliability of the data. For instance, according to Beisland and Mersland [53], the self-reporting nature of Mix Market may cause a reporting bias since the data is not collected and verified by a third party. As a result, there is potentially an overrepresentation of large MFIs in this dataset. However, this size bias is only minor. Mersland et al. [54] compared the median loan portfolio reported in Mix Market with information taken from credit rating reports provided by the Rating Fund II and found no big difference in the results.

We based our indicator of access to MFIs on the number of active borrowers in a particular country as a share of the total population. This indicator is widely used in a number of studies to measure the access to or outreach of MFI activities [55-57]. Finally, sector-specific output per capita data and data on real GDP growth were taken from the World Development Indicators [35].

\subsection{Empirical Model}

In this section, we develop our empirical model. We estimated the following model using an unbalanced panel that included over 80 low- and middle-income countries between 1995 and 2010 (Appendix $C$ lists the countries considered in this study).

$\Delta \ln \mathrm{y}_{i, t}=\alpha_{i}+\beta_{0} \ln y_{i, t-1}+\beta_{1}$ disaster $_{i, t}+\beta_{2} m f i_{i, t}+\beta_{3}\left(\right.$ disaster $\left._{i, t} * m f i_{i, t}\right)+X_{i, t-1}^{k}+\delta_{t}+\varepsilon_{i t}$

where $\Delta \ln y_{i t}$ represents the annual growth rate of each sector-specific value-added per capita output (agriculture, service, industry) in constant terms or real GDP growth in country $i$ at year $t$. We included the output in the previous year (in logarithms) to control for auto-regressive tendencies; $X^{k}$ is a vector of (lagged) control variables containing $k$ elements, and disaster ${ }_{i, t}$ is our constructed disaster variable outlined above, capturing the exogenous hazard exposure in a particular country year. Moreover, $m f i_{i, t}$ is our variable that contains our microfinance accessibility indicator based on the number of active borrowers. Additionally, we included an interaction term disaster $i_{i, t}{ }^{*} m f i_{i, t}$ in our specification to test for our hypothesis that access to lending facilities provided by MFIs mitigates part of the negative effect of disasters on economic development. Logically, if our hypothesis held, then we should have observed a statistically significant positive coefficient $\left(\beta_{3}>0\right)$ on the interaction term. The parameter $\alpha_{i}$ is a country-specific intercept to control for time-invariant characteristics such as geographical factors. By using countryspecific intercepts, we placed the emphasis of our analysis on the identification of the 
within-country variation over time. This approach reduced the influence of any potential selection bias that might have arisen, for example, if poorer countries were overrepresented in the disaster data due to the likelihood that disasters have a higher hazard risk to such countries [18]. Furthermore, the time-fixed effects $\left(\delta_{t}\right)$ controlled for shocks that affect all countries simultaneously. The final term $\varepsilon_{i t}$ is the error term. We estimated the model using the OLS estimator. To test for the appropriate panel data model and random or fixed effects, we used the Hausman test. It turned out that the null hypothesis of no country-specific effects was rejected at conventional levels of significance for all model specifications. Moreover, we assumed that our disaster indicator could be considered exogenous as it was primarily related to the physical magnitude of the natural event rather than associated with the vulnerability or exposure of the population, which was more endogenous. This assumption was also confirmed by the Durbin-Wu-Hausman test on identifying endogenous variables.

We based our vector of control variables on the existing studies on the macroeconomic impact of natural disasters [4,58-60]. These control variables helped us capture the omitted variables bias and were related to the macroeconomic environment and financial sector policies. To be specific, we considered the following variables as our controls: inflation rate, financial depth (private credit as a share of GDP), terms of trade (net barter terms of trade index), trade openness (exports plus imports as a share of GDP), government burden (government consumption as a share of GDP) and education attainment (gross secondary school enrolment rate) (see Appendix B for the data description of the control variables considered). To reduce any further endogeneity and simultaneity concerns, the control variables were included with a one-year lag.

The ability of MFIs to mitigate disaster effects might depend on their organizational structure. For instance, some MFIs operate as banks while others operate as non-bank financial institutions [30]. Under non-bank financial institutions arrangement, MFIs can be categorized as non-governmental organizations (NGOs) and credit unions. This distinction between banks and non-bank MFIs can be attributed to the differences in lending terms such as interest rates charged on loans, types of loan products (with NGOs and credit unions having a possibility of providing grants or soft loans, which is unlikely with banks), and the terms of loan replacement. Such differences in the lending terms can have great implications on the extent to which disaster victims can rehabilitate. Thus, the flexibility of MFIs in altering their lending rates, especially during times of hardships, can act as a fundamental policy action in ensuring that the pre-disaster living conditions for the victims are realized.

Besides the organizational structure, the response of MFIs in mitigating disaster effects can also depend on whether the institution is formally or informally operating. Many institutions that offer development programs in developing countries are typically informal, including many MFIs. Such MFIs provide informal and flexible financial instruments for disaster mitigation at the community level and within the informal economy [40]. This is supported by Shoji [61], who maintained that during the 1998 flood in Bangladesh, people accessed loans for rehabilitation from informal money lenders.

Additionally, the profitability status of MFIs also matters in disaster mitigation. MFIs raise their profits through loaning out the clients' savings, donations, and/or funds borrowed from external sources. However, during a disaster and soon after it, MFIs are faced with heavy withdrawals, no fresh savings, and non-repayment of existing loans (poorly performing loans), which can increase the portfolio-level problems of the MFI and even affect its solvency [37,62]. Moreover, the external borrowing of an MFI can also be affected because of the reduced loan repayment to their external lenders, and only MFIs with sufficient amounts of internally raised funds can remain supportive to their clients during a shock.

Finally, it is documented that the size of the clientele of an MFI influences its capacity to help disaster victims $[63,64]$. During a disaster and soon after a disaster, many clients need capital to rehabilitate [63]. However, some MFIs are found at the point of a liquidity 
crisis, given that individual savings and loan repayments are reduced with a disaster. To make matters worse for the MFI, savings withdrawals are likely to increase. Thus, if many clients are severely affected by a disaster, the MFI is more likely to fail to meet their financial demands. Moreover, the age of the MFI also matters in defining their degree of dealing with disaster effects. This can be attributed to their degree of efficiency. For instance, through the use of knowledge accumulated by old MFIs, new MFIs tend to be more efficient than old MFIs [51], and this can play a great role in defining the extent to which a given MFI can help its clients during a natural disaster.

\section{Empirical Results}

\subsection{Basic Findings}

In this section, we present our results on whether MFI activities can ease the adverse macroeconomic impact of natural disasters (for summary statistics see Appendix A). In columns 1-4 of Table 1 , we reported the results of a restrictive specification including only the initial level of output, the proxy for MFI access, the number of natural disasters (per square kilometer), and the interaction between the two latter variables. As the number of observations among the specifications and the availability of MFIs substantially differs among countries, we applied the bootstrap estimator with 1000 replicators to obtain robust standard errors and to reduce any sample selection issues. Surprisingly, the results on the rate of change in the real GDP per capita indicate that disasters have a significant positive effect on development, whereas the involvement of MFIs in the recovery process staggers economic development. One rational explanation for this finding is that adding all economic sectors together caused these surprising results. As already explained above, disasters have a non-uniform impact across economic sectors [4]. Therefore, we split aggregate GDP into three economic sectors in columns 2-4: agriculture, industry, and service. The results indicate that natural disasters stagger agricultural development, but benefit the service sector. The former result can be explained by the high vulnerability of the agricultural sector, whereas the latter result is explained by the resource inflows in terms of medical and housing facilities, food, and other forms of relief in the aftermath. On the interaction term, we found that MFI accessibility reduced the impact of disasters in the agricultural sector. To be precise, using the median value, the accessibility to MFIs reduced the impact of disasters by about 35 percent. In turn, we found no mitigation effect in the industry and service sectors. One explanation for this is that MFIs tend to support small loans, which may not significantly help the overall growth or even growth in the industry and service sectors that require sufficiently large amounts of capital that MFIs cannot afford to provide.

However, the results presented so far might have been driven by the lack of control variables, thus suffering from omitted variables bias. In columns 5-8, we re-estimated the same models as before, yet also included the control variables outlined in the previous section. Our findings indicate that we did not have any significant evidence of the mitigating effect of MFIs in any of the models. However, adding additional controls to our models created another concern, as some of the data on the covariates were not available for all country-years, making the panel data rather unbalanced. Including the suggested control variables in one specification reduced our number of observations by about one-third. This, in turn, increased the potential for a sample selection bias due to the exclusion of many developing countries, despite the majority of the damage caused by natural disasters occurring in these particular countries [65]. An alternative explanation for the insignificant results is that the set of MFIs included was rather heterogeneous. For instance, although some types of MFIs might effectively mitigate the disaster impact by providing liquidity, others may harm recovery by having hash repayment schedules or they might restrict lending, which is normally related to their organizational structure. Thus, in Table 2 below, we tried to answer the question of whether the nature of MFIs really matters in disaster mitigation. We distinguished between different MFI types (banks, NGOs, and credit unions). These categories were also interacted with the disaster measure. 
Table 1. Disasters, MFIs, and economic growth.

\begin{tabular}{|c|c|c|c|c|c|c|c|c|}
\hline & \multicolumn{8}{|c|}{ Dependent Variables } \\
\hline & $\begin{array}{c}\text { (1) } \\
\text { GDP } \\
\text { Growth }\end{array}$ & $\begin{array}{l}\text { (2) } \\
\text { Agricultural } \\
\text { Growth }\end{array}$ & $\begin{array}{c}\text { (3) } \\
\text { Industrial } \\
\text { Growth }\end{array}$ & $\begin{array}{c}\text { (4) } \\
\text { Service } \\
\text { Growth }\end{array}$ & $\begin{array}{c}\text { (5) } \\
\text { GDP } \\
\text { Growth }\end{array}$ & $\begin{array}{c}(6) \\
\text { Agricultural } \\
\text { Growth }\end{array}$ & $\begin{array}{c}\text { (7) } \\
\text { Industrial } \\
\text { Growth }\end{array}$ & $\begin{array}{c}\text { (8) } \\
\text { Service } \\
\text { Growth }\end{array}$ \\
\hline Initial output, in logs & $\begin{array}{c}0.186^{* * *} \\
(3.86)\end{array}$ & $\begin{array}{c}-0.239 * * * \\
(-8.14)\end{array}$ & $\begin{array}{c}-0.063^{* * *} \\
(-3.54)\end{array}$ & $\begin{array}{c}-0.035 \text { ** } \\
(-2.22)\end{array}$ & $\begin{array}{l}-0.001 \\
(-0.03)\end{array}$ & $\begin{array}{c}-0.385 * * * \\
(-6.44)\end{array}$ & $\begin{array}{c}-0.202^{* * *} \\
(-6.00)\end{array}$ & $\begin{array}{c}-0.207^{* * *} \\
(-4.14)\end{array}$ \\
\hline Disaster & $\begin{array}{c}0.0001 \text { * } \\
(1.73)\end{array}$ & $\begin{array}{c}-0.0002 \\
(-1.67)\end{array}$ & $\begin{array}{l}0.001 \\
(1.37)\end{array}$ & $\begin{array}{c}0.001 * * \\
(2.17)\end{array}$ & $\begin{array}{l}0.0001 \\
(0.84)\end{array}$ & $\begin{array}{l}-0.001 \\
(-1.27)\end{array}$ & $\begin{array}{l}0.001 \\
(1.10)\end{array}$ & $\begin{array}{c}0.0001 \\
(0.33)\end{array}$ \\
\hline MFIs & $\begin{array}{l}-0.003 \\
(-0.13)\end{array}$ & $\begin{array}{l}0.105 \\
(0.92)\end{array}$ & $\begin{array}{l}0.251 \\
(0.74)\end{array}$ & $\begin{array}{l}0.190 \\
(0.71)\end{array}$ & $\begin{array}{l}0.049 \\
(0.47)\end{array}$ & $\begin{array}{l}0.435 * \\
(1.88)\end{array}$ & $\begin{array}{c}1.081 \text { ** } \\
(2.60)\end{array}$ & $\begin{array}{l}0.628 \\
(1.24)\end{array}$ \\
\hline Disaster ${ }^{*}$ MFIs & $\begin{array}{c}-0.003^{* * *} \\
(-2.96)\end{array}$ & $\begin{array}{c}0.013^{* * *} \\
(4.17)\end{array}$ & $\begin{array}{l}0.006 \\
(0.89)\end{array}$ & $\begin{array}{l}-0.004 \\
(-0.86)\end{array}$ & $\begin{array}{l}-0.002 \\
(-0.77)\end{array}$ & $\begin{array}{l}0.015 \\
(1.45)\end{array}$ & $\begin{array}{l}-0.010 \\
(-0.62)\end{array}$ & $\begin{array}{l}0.003 \\
(0.46)\end{array}$ \\
\hline Education attainment & & & & & $\begin{array}{l}0.006 \\
(0.39)\end{array}$ & $\begin{array}{l}0.047 \\
(1.26)\end{array}$ & $\begin{array}{l}0.060 \\
(0.85)\end{array}$ & $\begin{array}{l}0.068 \\
(1.07)\end{array}$ \\
\hline Financial depth & & & & & $\begin{array}{c}-0.038^{* * *} \\
(-4.99)\end{array}$ & $\begin{array}{l}0.011 \\
(0.81)\end{array}$ & $\begin{array}{c}-0.086^{* * *} \\
(-2.69)\end{array}$ & $\begin{array}{c}-0.093^{* * *} \\
(-2.90)\end{array}$ \\
\hline Government burden & & & & & $\begin{array}{l}0.006 \\
(1.18)\end{array}$ & $\begin{array}{c}0.024^{* *} \\
(2.38)\end{array}$ & $\begin{array}{c}0.134^{* * *} \\
(4.26)\end{array}$ & $\begin{array}{c}0.158^{* * *} \\
(3.45)\end{array}$ \\
\hline Inflation & & & & & $\begin{array}{c}-0.033^{* *} \\
(-2.14)\end{array}$ & $\begin{array}{l}-0.050 \\
(-0.80)\end{array}$ & $\begin{array}{c}0.118^{*} \\
(1.78)\end{array}$ & $\begin{array}{l}0.077 \\
(0.92)\end{array}$ \\
\hline Trade openness & & & & & $\begin{array}{c}0.038^{* * *} \\
(3.52)\end{array}$ & $\begin{array}{l}0.011 \\
(0.49)\end{array}$ & $\begin{array}{c}0.113^{* *} \\
(2.02)\end{array}$ & $\begin{array}{c}0.128 * * \\
(2.28)\end{array}$ \\
\hline Terms of trade & & & & & $\begin{array}{c}0.028 * \\
(2.60)\end{array}$ & $\begin{array}{c}0.056^{*} \\
(1.73)\end{array}$ & $\begin{array}{l}0.016 \\
(0.22)\end{array}$ & $\begin{array}{l}0.056 \\
(1.01)\end{array}$ \\
\hline Observations & 924 & 835 & 866 & 863 & 641 & 597 & 606 & 603 \\
\hline Countries & 84 & 77 & 82 & 82 & 65 & 60 & 64 & 64 \\
\hline
\end{tabular}

Results are generated using the fixed effects method. All models include a constant, country, and year fixed effects. Errors are clustered at the country level. t-statistics are reported in parenthesis. ${ }^{*} p<0.10,{ }^{* *} p<0.05,{ }^{* * *} p<0.01$.

Table 2. Disasters, specific MFIs, and economic growth.

\begin{tabular}{|c|c|c|c|c|c|c|c|c|}
\hline & \multicolumn{8}{|c|}{ Dependent Variables } \\
\hline & $\begin{array}{c}\text { (1) } \\
\text { GDP } \\
\text { Growth }\end{array}$ & $\begin{array}{l}\text { (2) } \\
\text { Agricultural } \\
\text { Growth }\end{array}$ & $\begin{array}{c}\text { (3) } \\
\text { Industrial } \\
\text { Growth }\end{array}$ & $\begin{array}{c}\text { (4) } \\
\text { Service } \\
\text { Growth }\end{array}$ & $\begin{array}{c}\text { (5) } \\
\text { GDPGrowth }\end{array}$ & $\begin{array}{l}\text { (6) } \\
\text { Agricultural } \\
\text { Growth }\end{array}$ & $\begin{array}{c}(7) \\
\text { Industrial } \\
\text { Growth }\end{array}$ & $\begin{array}{c}\text { (8) } \\
\text { Service } \\
\text { Growth }\end{array}$ \\
\hline Initial output, in logs & $\begin{array}{l}0.188 * * * \\
(3.78)\end{array}$ & $\begin{array}{c}-0.254^{* * *} \\
(-7.83)\end{array}$ & $\begin{array}{c}-0.089^{* * *} \\
(-4.66)\end{array}$ & $\begin{array}{c}-0.055^{* * *} \\
(-3.29)\end{array}$ & $\begin{array}{l}-0.007 \\
(-0.13)\end{array}$ & $\begin{array}{c}-0.376^{* * *} \\
(-6.09)\end{array}$ & $\begin{array}{c}-0.199 * * * \\
(-5.92)\end{array}$ & $\begin{array}{c}-0.205^{* * *} \\
(-4.19)\end{array}$ \\
\hline Disaster & $\begin{array}{c}0.0001 \\
(0.66)\end{array}$ & $\begin{array}{l}-0.0001 \\
(-0.71)\end{array}$ & $\begin{array}{c}0.0004 \\
(1.22)\end{array}$ & $\begin{array}{c}0.001 \text { ** } \\
(2.04)\end{array}$ & $\begin{array}{l}0.0002 \\
(1.44)\end{array}$ & $\begin{array}{l}-0.001 \\
(-1.42)\end{array}$ & $\begin{array}{l}0.001 \\
(0.81)\end{array}$ & $\begin{array}{c}0.0003 \\
(0.47)\end{array}$ \\
\hline MFIs (banks) & $\begin{array}{l}0.080 \\
(0.59)\end{array}$ & $\begin{array}{c}0.767^{* * *} \\
(5.50)\end{array}$ & $\begin{array}{c}2.624^{* * *} \\
(6.11)\end{array}$ & $\begin{array}{c}2.147^{* * * *} \\
(3.46)\end{array}$ & $\begin{array}{l}0.144 \\
(0.78)\end{array}$ & $\begin{array}{l}0.544 \\
(1.50)\end{array}$ & $\begin{array}{c}1.807^{* * *} \\
(3.07)\end{array}$ & $\begin{array}{c}2.223 * * * \\
(3.61)\end{array}$ \\
\hline MFIs (NGOs) & $\begin{array}{l}0.188 \\
(1.25)\end{array}$ & $\begin{array}{l}0.198 \\
(0.33)\end{array}$ & $\begin{array}{l}1.359 \\
(0.90)\end{array}$ & $\begin{array}{l}1.168 \\
(0.90)\end{array}$ & $\begin{array}{l}0.196 \\
(1.63)\end{array}$ & $\begin{array}{l}-0.222 \\
(-0.40)\end{array}$ & $\begin{array}{l}0.105 \\
(0.09)\end{array}$ & $\begin{array}{l}-0.662 \\
(-0.77)\end{array}$ \\
\hline MFIs (credit) & $\begin{array}{l}-0.048 \\
(-0.21)\end{array}$ & $\begin{array}{l}-0.051 \\
(-0.21)\end{array}$ & $\begin{array}{l}1.819 \\
(1.31)\end{array}$ & $\begin{array}{l}0.125 \\
(0.11)\end{array}$ & $\begin{array}{c}-0.308^{* * *} \\
(-2.72)\end{array}$ & $\begin{array}{l}-0.075 \\
(-0.34)\end{array}$ & $\begin{array}{l}0.071 \\
(0.09)\end{array}$ & $\begin{array}{c}-1.643^{* *} \\
(-2.37)\end{array}$ \\
\hline $\begin{array}{l}\text { Disaster * MFIs } \\
\quad \text { (banks) }\end{array}$ & $\begin{array}{l}-0.008 \\
(-1.44)\end{array}$ & $\begin{array}{l}0.033 \\
(1.49)\end{array}$ & $\begin{array}{l}0.041 \\
(1.09)\end{array}$ & $\begin{array}{l}-0.020 \\
(-0.93)\end{array}$ & $\begin{array}{l}-0.016 \\
(-1.37)\end{array}$ & $\begin{array}{l}0.048 \\
(1.56)\end{array}$ & $\begin{array}{l}0.007 \\
(0.15)\end{array}$ & $\begin{array}{l}-0.013 \\
(-0.23)\end{array}$ \\
\hline $\begin{array}{l}\text { Disaster * MFIs } \\
\text { (NGOs) }\end{array}$ & $\begin{array}{l}-0.009 \\
(-0.57)\end{array}$ & $\begin{array}{c}0.118^{* * *} \\
(4.16)\end{array}$ & $\begin{array}{l}0.038 \\
(0.55)\end{array}$ & $\begin{array}{l}0.010 \\
(0.70)\end{array}$ & $\begin{array}{l}0.002 \\
(0.29)\end{array}$ & $\begin{array}{c}0.110^{* * *} \\
(4.47)\end{array}$ & $\begin{array}{l}0.055 \\
(0.95)\end{array}$ & $\begin{array}{l}0.056 \\
(0.76)\end{array}$ \\
\hline $\begin{array}{l}\text { Disaster * MFIs } \\
\text { (credit) }\end{array}$ & $0.040 * *$ & $\begin{array}{l}-0.052 \\
(-0.82)\end{array}$ & $\begin{array}{l}-0.116 \\
(-0.99)\end{array}$ & $\begin{array}{l}0.054 \\
(0.70)\end{array}$ & $\begin{array}{l}-0.026 \\
(-0.45)\end{array}$ & $-0.279 *$ & 0.485 & $0.969 * * *$ \\
\hline $\begin{array}{l}\text { Observations } \\
\text { Countries }\end{array}$ & $\begin{array}{c}(2.09) \\
924 \\
84\end{array}$ & $\begin{array}{c}(-0.82) \\
835 \\
77\end{array}$ & $\begin{array}{c}(-0.99) \\
866 \\
82\end{array}$ & $\begin{array}{l}(0.8) \\
863 \\
82\end{array}$ & $\begin{array}{c}(-0.45) \\
641 \\
65\end{array}$ & $\begin{array}{c}(-1.68) \\
597 \\
60\end{array}$ & $\begin{array}{c}(1.41) \\
606 \\
64\end{array}$ & $\begin{array}{c}(2.00) \\
603 \\
64\end{array}$ \\
\hline
\end{tabular}

Results are generated using the fixed effects method. All models include a constant, country, and year fixed effects. Models 5, 6, 7, and 8 are estimated including the control variables from Table 1. Errors are clustered at the country level. $t$-statistics are reported in parenthesis. ${ }^{*} p<0.10,{ }^{* *} p<0.05,{ }^{* * *} p<0.01$.

From the results in Table 2 we drew a number of conclusions. First, in any of the specifications, reported disasters had a general or sector-specific effect. Second, regardless of any disaster events, MFIs that operated as banks had a positive impact on the growth of the industrial and service sectors. In turn, cooperatives or credit unions had a negative effect on the economic development in the service sector. Moreover, the results demonstrate 
that NGOs can stimulate the agricultural sector in case of a natural event, whereas credit unions can do better for the service sector. One rational explanation for this finding is that cooperatives are typically owned and managed by self-selected group members, which makes it easier to decide and allocate resources to service provisions such as health facilities, water, and sanitation, etc., whereas NGOs may be managed by outsiders who might dictate and allocate resources to agriculture so as to increase food production because food shortage is easily observable.

Next, we explored whether it matters if an MFI is regarded as a non-profit or for-profit intermediary. This examination was based on the argument that for-profit intermediaries may not offer soft loans and are even more risk-averse regarding loan default. On the other hand, non-profit intermediaries can quickly provide soft loans or even alter their repayment procedures since their driving motive is not profit-making. The results in Table 3 generally indicate that regardless of whether a disaster occurred in a particular year, MFIs supported the growth of specific sectors. Surprisingly, we found no effect on the aggregate GDP growth, possibly because of combining of all sectors into one variable. The reason why for-profit MFIs are better at creating economic development is that they have the option to select only high-return investment opportunities that might enhance economic development. In addition, they have a larger incentive in monitoring the activities of their clients. Due to their business model, these MFIs are usually also more subject to regulation. However, after a disaster, non-profit organizations are better able to stimulate recovery than for-profit MFIs, possibly because for-profit MFIs can refrain from providing loans to victims due to the likely high risk of default, whereas non-profitable MFIs may decide to extend assistance to victims with the aim of expanding their clientele. Secondly, for-profit MFIs may stick to hard loans compared to non-profitable MFIs (soft loans), which instead affect their clients during the rehabilitation process.

Table 3. Disasters, profitability of MFIs, and economic growth.

\begin{tabular}{|c|c|c|c|c|c|c|c|c|}
\hline & \multicolumn{8}{|c|}{ Dependent Variables } \\
\hline & $\begin{array}{c}\text { (1) } \\
\text { GDP } \\
\text { Growth }\end{array}$ & $\begin{array}{l}\quad(2) \\
\text { Agricultural } \\
\text { Growth }\end{array}$ & $\begin{array}{c}\text { (3) } \\
\text { Industrial } \\
\text { Growth }\end{array}$ & $\begin{array}{c}\quad(4) \\
\text { Service } \\
\text { Growth }\end{array}$ & $\begin{array}{c}\text { (5) } \\
\text { GDP } \\
\text { Growth }\end{array}$ & $\begin{array}{l}\text { (6) } \\
\text { Agricultural } \\
\text { Growth }\end{array}$ & $\begin{array}{c}\text { (7) } \\
\text { Industrial } \\
\text { Growth }\end{array}$ & $\begin{array}{l}\quad(8) \\
\text { Service } \\
\text { Growth }\end{array}$ \\
\hline Initial output, in logs & $\begin{array}{c}0.186^{* * *} \\
(3.81)\end{array}$ & $\begin{array}{c}-0.249 * * * \\
(-7.89)\end{array}$ & $\begin{array}{c}-0.073^{* * *} \\
(-4.02)\end{array}$ & $\begin{array}{l}-0.042 * * \\
(-2.59)\end{array}$ & $\begin{array}{l}-0.006 \\
(-0.12)\end{array}$ & $\begin{array}{c}-0.403^{* * *} \\
(-6.82)\end{array}$ & $\begin{array}{c}-0.207 \text { *** } \\
(-5.93)\end{array}$ & $\begin{array}{c}-0.212 * * * \\
(-4.36)\end{array}$ \\
\hline Disaster & $\begin{array}{c}0.0001 \\
(1.12)\end{array}$ & $\begin{array}{c}-0.0001 \\
(-1.09)\end{array}$ & $\begin{array}{l}0.001 \\
(1.44)\end{array}$ & $\begin{array}{c}0.001 * \\
(1.87)\end{array}$ & $\begin{array}{c}0.0002 \\
(0.99)\end{array}$ & $\begin{array}{l}-0.001 \\
(-0.98)\end{array}$ & $\begin{array}{l}0.002 \\
(1.30)\end{array}$ & $\begin{array}{l}0.001 \\
(1.34)\end{array}$ \\
\hline Profitable MFIs & $\begin{array}{l}-0.014 \\
(-0.84)\end{array}$ & $\begin{array}{l}0.051 \\
(0.67)\end{array}$ & $\begin{array}{l}0.075 \\
(0.36)\end{array}$ & $\begin{array}{l}0.053 \\
(0.30)\end{array}$ & $\begin{array}{l}0.225 \\
(1.24)\end{array}$ & $\begin{array}{c}0.921 * * \\
(2.64)\end{array}$ & $\begin{array}{c}1.821^{* * *} \\
(3.54)\end{array}$ & $\begin{array}{c}2.287^{* * *} \\
(4.16)\end{array}$ \\
\hline Non-profitable MFIs & $\begin{array}{l}0.096 \\
(1.26)\end{array}$ & $\begin{array}{c}0.648 * * \\
(2.47)\end{array}$ & $\begin{array}{c}2.172 * * * \\
(4.14)\end{array}$ & $\begin{array}{c}1.629 * * * \\
(3.40)\end{array}$ & $\begin{array}{l}-0.109 \\
(-0.94)\end{array}$ & $\begin{array}{l}-0.217 \\
(-1.00)\end{array}$ & $\begin{array}{l}0.202 \\
(0.38)\end{array}$ & $\begin{array}{l}-0.994 * \\
(-1.84)\end{array}$ \\
\hline $\begin{array}{c}\text { Disaster * Profitable } \\
\text { MFIs }\end{array}$ & 0.002 & $0.008^{* * *}$ & 0.002 & -0.0004 & -0.003 & 0.009 & -0.017 & -0.007 \\
\hline & $(-1.16)$ & $(3.46)$ & $(0.31)$ & $(-0.08)$ & $(-1.04)$ & $(1.16)$ & $(-0.96)$ & $(-0.97)$ \\
\hline $\begin{array}{c}\text { Disaster * } \\
\text { Non-profitable MFIs }\end{array}$ & $-0.006^{* * *}$ & $0.017^{* *}$ & -0.003 & $-0.021^{* * *}$ & 0.006 & $0.153^{* *}$ & 0.103 & $0.132 * *$ \\
\hline & $(-3.10)$ & $(2.42)$ & $(-0.44)$ & $(-3.02)$ & $(0.65)$ & $(2.22)$ & $(1.76)$ & $(2.08)$ \\
\hline Observations & 924 & 835 & 866 & 863 & 641 & 597 & 606 & 603 \\
\hline Countries & 84 & 77 & 82 & 82 & 65 & 60 & 64 & 64 \\
\hline
\end{tabular}

Results are generated using fixed effects method. All models include a constant, country, and year fixed effects. Models 5, 6, 7, and 8 are estimated including the control variables from Table 1 . Errors are clustered at the country level. t-statistics are reported in parenthesis. ${ }^{*} p<0.10,{ }^{* *} p<0.05,{ }^{* * *} p<0.01$.

We now turn, in Table 4, to the legal status of MFIs. The legal status of any institution ascertains its legitimacy to operate in a given country. Secondly, it provides it with the legality of accessing funds from the government and other supporting institutions. For example, in Uganda, fully registered MFIs can access funds from the microfinance support center, which is owned by the government, to increase their liquidity. Upon this background, it became necessary to examine the behaviors of formal and informal MFIs in addressing disaster effects. It is documented [40,61] that informal financial institutions play a fundamental role in dealing with disaster effects. These informal financial institutions 
provide not only informal credit, especially to the poor, but also provide informal insurance strategies that help the masses deal with various disaster effects. Thus, we tested the hypothesis that in developing countries, informal MFIs are more supportive in helping disaster victims than formal MFIs. To test for this, we estimated models when our MFI indicator was split along the lines of regulated and non-regulated MFIs to proxy for formal and informal MFIs, respectively. The results in Table 4 suggest that during regular times regulated MFIs were better able to stimulate economic development, whereas in times of hardship, the story changed. This finding supports Kumar and Newport [40] and Shoji [61], who observed that informal financial institutions play a fundamental role in dealing with disaster effects. The possible explanation for this finding could be in line with the binding conditions that regulated MFIs acquire after registration, for example, defining their area of operation, not giving out loans exceeding a certain amount, regulating their capital base, beneficiaries' age groups, etc. Such restrictions may not apply to the non-regulated MFIs, which puts them in a better position of helping disaster victims.

Table 4. Disasters, MFI legal status, and economic growth.

\begin{tabular}{|c|c|c|c|c|c|c|c|c|}
\hline & \multicolumn{8}{|c|}{ Dependent Variables } \\
\hline & $\begin{array}{c}\text { (1) } \\
\text { GDP } \\
\text { Growth }\end{array}$ & $\begin{array}{l}\text { (2) } \\
\text { Agricultural } \\
\text { Growth }\end{array}$ & $\begin{array}{c}\text { (3) } \\
\text { Industrial } \\
\text { Growth }\end{array}$ & $\begin{array}{l}\quad(4) \\
\text { Service } \\
\text { Growth }\end{array}$ & $\begin{array}{c}\text { (5) } \\
\text { GDP } \\
\text { Growth }\end{array}$ & $\begin{array}{l}\text { (6) } \\
\text { Agricultural } \\
\text { Growth }\end{array}$ & $\begin{array}{c}\text { (7) } \\
\text { Industrial } \\
\text { Growth }\end{array}$ & $\begin{array}{c}\text { (8) } \\
\text { Service } \\
\text { Growth }\end{array}$ \\
\hline Initial output, in logs & $\begin{array}{c}0.183^{* * *} \\
(3.70)\end{array}$ & $\begin{array}{c}-0.274 * * * \\
(-8.23)\end{array}$ & $\begin{array}{c}-0.102 * * * \\
(-4.81)\end{array}$ & $\begin{array}{c}-0.066^{* * *} \\
(-3.65)\end{array}$ & $\begin{array}{l}-0.002 \\
(-0.03)\end{array}$ & $\begin{array}{c}-0.402^{* * *} \\
(-6.68)\end{array}$ & $\begin{array}{c}-0.209 * * * \\
(-5.85)\end{array}$ & $\begin{array}{c}-0.215^{* * *} \\
(-4.20)\end{array}$ \\
\hline Disaster & $\begin{array}{c}0.0001 \\
(1.82)\end{array}$ & $\begin{array}{c}-0.0001 \\
(0.67)\end{array}$ & $\begin{array}{c}0.001 * * \\
(2.08)\end{array}$ & $\begin{array}{c}0.001 * * * \\
(3.03)\end{array}$ & $\begin{array}{c}0.0001 \\
(0.84)\end{array}$ & $\begin{array}{l}-0.001 \\
(-1.07)\end{array}$ & $\begin{array}{l}0.001 \\
(1.23)\end{array}$ & $\begin{array}{c}0.0002 \\
(0.52)\end{array}$ \\
\hline Regulated MFIs & $\begin{array}{l}0.079 \\
(0.82)\end{array}$ & $\begin{array}{c}0.793 * * * \\
(4.40)\end{array}$ & $\begin{array}{c}2.563 * * * \\
(6.46)\end{array}$ & $\begin{array}{c}2.017 * * * \\
(4.96)\end{array}$ & $\begin{array}{l}0.065 \\
(0.48)\end{array}$ & $\begin{array}{l}0.592^{* *} \\
(2.41)\end{array}$ & $\begin{array}{c}1.491^{* * *} \\
(3.76)\end{array}$ & $\begin{array}{c}1.316^{* *} \\
(2.36)\end{array}$ \\
\hline Non-regulated MFIs & $\begin{array}{c}-0.1011^{* * *} \\
(-3.35)\end{array}$ & $\begin{array}{c}-0.303^{* * *} \\
(-3.79)\end{array}$ & $\begin{array}{c}-0.421 * * * \\
(-3.81)\end{array}$ & $\begin{array}{c}-0.390 * * * \\
(-3.73)\end{array}$ & $\begin{array}{l}-0.050 \\
(-0.16)\end{array}$ & $\begin{array}{l}-1.107 \\
(-1.63)\end{array}$ & $\begin{array}{l}-1.306 \\
(-0.93)\end{array}$ & $\begin{array}{l}-3.003 \\
(-1.92)\end{array}$ \\
\hline Disaster * Regulated & $-0.005^{* * *}$ & 0.005 & $-0.011^{* *}$ & $-0.017^{* * *}$ & -0.002 & 0.010 & -0.014 & 0.0004 \\
\hline & $(-4.25)$ & $(1.54)$ & $(-2.22)$ & $(-3.21)$ & $(-0.80)$ & $(1.20)$ & $(-0.87)$ & $(-0.05)$ \\
\hline $\begin{array}{c}\text { Disaster * } \\
\text { Non-regulated MFIs }\end{array}$ & $0.048^{* *}$ & $0.188^{* * *}$ & $0.194^{* * *}$ & $0.165^{* *}$ & 0.005 & $0.292 * * *$ & $0.185^{* *}$ & $0.199 *$ \\
\hline & $(2.43)$ & $(3.44)$ & $(2.90)$ & $(2.49)$ & $(0.22)$ & (3.09) & $(2.01)$ & (1.76) \\
\hline Observations & 924 & 835 & 866 & 863 & 641 & 597 & 606 & 603 \\
\hline Countries & 84 & 77 & 82 & 82 & 65 & 60 & 64 & 64 \\
\hline
\end{tabular}

Results are generated using fixed effects method. All models include a constant, country, and year fixed effects. Models 5, 6, 7, and 8 are estimated including the control variables from Table 1. Errors are clustered at the country level. t-statistics are reported in parenthesis. ${ }^{*} p<0.10,{ }^{* *} p<0.05,{ }^{* * *} p<0.01$.

More still, based on Hermes et al. [51], we also investigated whether the age of MFIs (measured as survival time since establishment) influences the extent of their intervention in dealing with disaster effects. Hermes et al. [51] found old MFIs to be less efficient than new MFIs. They attributed this to knowledge acquisition by the new MFIs that was already accumulated by the old MFIs. We tried to test for this with our data by introducing our MFI indicator in the analysis when it was divided along the lines of age (young and mature). In our analysis, young MFIs were constructed as a sum of new and young MFIs as classified by Mix Market. The results in Table 5 suggest that during regular times young MFIs were better at stimulating economic development than mature MFIs. However, during times of disaster, mature MFIs seemed to contribute more than young MFIs toward development. The argument is supported by the growth in the agricultural sector. One reason for this is that mature MFIs might have accumulated enough information about their clients, making it easier to screen them for loans during hard times. This may not be possible for young MFIs, thereby leaving them with limited options of restricting the amount and/or the number of loans. 
Table 5. Disasters, age of MFIs, and economic growth.

\begin{tabular}{|c|c|c|c|c|c|c|c|c|}
\hline & \multicolumn{8}{|c|}{ Dependent Variables } \\
\hline & $\begin{array}{c}\text { (1) } \\
\text { GDP } \\
\text { Growth }\end{array}$ & $\begin{array}{l}\text { (2) } \\
\text { Agricultural } \\
\text { Growth }\end{array}$ & $\begin{array}{l}\text { (3) } \\
\text { Industrial } \\
\text { Growth }\end{array}$ & $\begin{array}{c}\text { (4) } \\
\text { Service } \\
\text { Growth }\end{array}$ & $\begin{array}{c}\text { (5) } \\
\text { GDP } \\
\text { Growth }\end{array}$ & $\begin{array}{l}\text { (6) } \\
\text { Agricultural } \\
\text { Growth }\end{array}$ & $\begin{array}{c}(7) \\
\text { Industrial } \\
\text { Growth }\end{array}$ & $\begin{array}{c}\text { (8) } \\
\text { Service } \\
\text { Growth }\end{array}$ \\
\hline Initial output, in logs & $\begin{array}{c}0.185^{* * *} \\
(3.81)\end{array}$ & $\begin{array}{c}-0.239^{* * *} \\
(-8.29)\end{array}$ & $\begin{array}{c}-0.067^{* * *} \\
(-3.83)\end{array}$ & $\begin{array}{c}-0.039 * * \\
(-2.53)\end{array}$ & $\begin{array}{l}-0.004 \\
(-0.09)\end{array}$ & $\begin{array}{c}-0.388^{* * *} \\
(-6.52)\end{array}$ & $\begin{array}{c}-0.198^{* * *} \\
(-5.99)\end{array}$ & $\begin{array}{c}-0.203 * * * * \\
(-4.09)\end{array}$ \\
\hline Disaster & $\begin{array}{c}0.0001 \\
(1.41)\end{array}$ & $\begin{array}{c}-0.0003 \\
(-1.24)\end{array}$ & $\begin{array}{c}0.0004 \\
(0.94)\end{array}$ & $\begin{array}{c}0.0005 \\
(1.63)\end{array}$ & $\begin{array}{c}0.00004 \\
(0.18)\end{array}$ & $\begin{array}{l}-0.001 \\
(-1.24)\end{array}$ & $\begin{array}{l}0.002 \\
(1.02)\end{array}$ & $\begin{array}{c}0.0002 \\
(0.19)\end{array}$ \\
\hline Young MFIs & $\begin{array}{l}0.376 \\
(1.60)\end{array}$ & $\begin{array}{c}1.380^{* *} \\
(2.32)\end{array}$ & $\begin{array}{c}4.869^{* * *} \\
(2.80)\end{array}$ & $\begin{array}{c}4.038^{* * *} \\
(3.24)\end{array}$ & $\begin{array}{l}0.416^{*} \\
(1.79)\end{array}$ & $\begin{array}{l}0.855 \\
(1.56)\end{array}$ & $\begin{array}{c}4.249^{* *} \\
(2.55)\end{array}$ & $\begin{array}{c}2.516^{* *} \\
(2.14)\end{array}$ \\
\hline Mature MFIs & $\begin{array}{l}-0.011 \\
(-0.53)\end{array}$ & $\begin{array}{l}0.083 \\
(0.76)\end{array}$ & $\begin{array}{l}0.174 \\
(0.53)\end{array}$ & $\begin{array}{l}0.120 \\
(0.47)\end{array}$ & $\begin{array}{l}0.023 \\
(0.25)\end{array}$ & $\begin{array}{c}0.425^{*} \\
(1.96)\end{array}$ & $\begin{array}{c}1.033^{* *} \\
(2.62)\end{array}$ & $\begin{array}{l}0.502 \\
(1.16)\end{array}$ \\
\hline Disaster * Young MFIs & $\begin{array}{l}-0.004 \\
(-0.50)\end{array}$ & $\begin{array}{l}0.017 \\
(1.54)\end{array}$ & $\begin{array}{l}0.004 \\
(0.16)\end{array}$ & $\begin{array}{l}-0.013 \\
(-0.25)\end{array}$ & $\begin{array}{l}0.009 \\
(0.41)\end{array}$ & $\begin{array}{l}0.100 \\
(1.03)\end{array}$ & $\begin{array}{l}-0.177 \\
(-0.86)\end{array}$ & $\begin{array}{l}-0.005 \\
(-0.06)\end{array}$ \\
\hline Disaster * Mature MFIs & $\begin{array}{c}-0.004^{* * *} \\
(-3.89)\end{array}$ & $\begin{array}{c}0.013^{* * *} \\
(2.77)\end{array}$ & $\begin{array}{l}0.008 \\
(0.88)\end{array}$ & $\begin{array}{l}-0.001 \\
(-0.25)\end{array}$ & $\begin{array}{l}-0.001 \\
(-0.54)\end{array}$ & $\begin{array}{l}0.017 \\
(1.56)\end{array}$ & $\begin{array}{l}-0.014 \\
(-0.69)\end{array}$ & $\begin{array}{l}0.004 \\
(0.43)\end{array}$ \\
\hline Observations & 924 & 835 & 866 & 863 & 641 & 597 & 606 & 603 \\
\hline Countries & 84 & 77 & 82 & 82 & 65 & 60 & 64 & 64 \\
\hline
\end{tabular}

Results are generated using fixed effects method. All models include a constant, country, and year fixed effects. Models 5, 6, 7, and 8 are estimated including the control variables from Table 1 . Errors are clustered at the country level. $t$-statistics are reported in parenthesis. ${ }^{*} p<0.10,{ }^{* *} p<0.05,{ }^{* * *} p<0.01$.

Besides the age of MFIs, we also investigated whether the number of clients served by MFIs can influence the extent to which they can deal with disaster effects. During a disaster and soon after, many clients need capital to rehabilitate [63]. As a result, many victims may apply for loans from MFIs, forcing them to be more selective in determining beneficiaries. Thus, their aggregate impact across regions or even among individuals may be significantly small. We tested for this argument by splitting our MFI indicator along the lines of outreach to proxy for the number of clients. The results in Table 6 generally indicate that MFIs with large outreach potential boosted economic development during regular times and during times of a disaster. Their support was more evident in the agricultural sector. A similar result was revealed by the medium outreach MFIs (small outreach MFIs were only helpful in the restrictive model 2). MFIs whose outreach capacity was relatively strong were likely to have a larger capital base compared to those with a smaller outreach capacity, which enabled them to support a country's development even during times of hardships. (we also tested the argument that the extent to which MFIs can help disaster victims depends on their degree of transparency in distributing relief. For this purpose, we constructed a diamond dummy indicating the reliability and quality of the MFI data. Our dummy took a value of 1 if the diamond score for a particular MFI was above 4 , and 0 otherwise. Our results suggest that when disasters occur, the transparency of MFIs does not matter in aiding growth (detailed results are available upon request).)

\subsection{Robustness Checks}

This section checks the robustness of our results against the effects of a lagged MFI indicator on the impact of disasters on growth, MFI response to specific disaster effects, endogeneity, and the dynamics of disasters on growth. First, the results presented in Table 1 explain the contemporaneous effects of disasters on economic growth and the role of MFIs in mitigating these effects. However, one can argue that disasters also affect the activities of an MFI, for instance, through the destruction of its assets, which in turn affects its degree of intervention. In particular, it is possible that natural disasters cause liquidity squeezes and MFIs may fail to respond to a boom in credit demand due to the need to restore the destroyed and damaged MFI buildings and infrastructure [31]. For this reason, entering our MFI accessibility indicator for a specific country-year may have cast doubt on our results. To address this issue, we instead used the first lag of the MFI accessibility indicator and the corresponding interaction term in our regressions. The results in Table 7 robustly support the findings in Table 1 that in the aftermath, MFIs tended to remain more supportive of agriculture than of industry and service sectors. 
Table 6. Disasters, MFI outreach, and economic growth.

\begin{tabular}{|c|c|c|c|c|c|c|c|c|}
\hline & \multicolumn{8}{|c|}{ Dependent Variables } \\
\hline & $\begin{array}{c}\text { (1) } \\
\text { GDP } \\
\text { Growth }\end{array}$ & $\begin{array}{l}\text { (2) } \\
\text { Agricultural } \\
\text { Growth }\end{array}$ & $\begin{array}{c}\text { (3) } \\
\text { Industrial } \\
\text { Growth }\end{array}$ & $\begin{array}{c}\text { (4) } \\
\text { Service } \\
\text { Growth }\end{array}$ & $\begin{array}{c}\text { (5) } \\
\text { GDP } \\
\text { Growth }\end{array}$ & $\begin{array}{c}\text { (6) } \\
\text { Agricultural } \\
\text { Growth }\end{array}$ & $\begin{array}{c}\text { (7) } \\
\text { Industrial } \\
\text { Growth }\end{array}$ & $\begin{array}{c}\text { (8) } \\
\text { Service } \\
\text { Growth }\end{array}$ \\
\hline Initial output, in logs & $\begin{array}{c}0.188^{* * *} \\
(3.85)\end{array}$ & $\begin{array}{c}-0.237 * * * \\
(-8.22)\end{array}$ & $\begin{array}{c}-0.065^{* * *} \\
(-3.64)\end{array}$ & $\begin{array}{c}-0.036^{* *} \\
(-2.23)\end{array}$ & $\begin{array}{l}-0.009 \\
(-0.17)\end{array}$ & $\begin{array}{c}-0.409^{* * *} \\
(-6.76)\end{array}$ & $\begin{array}{c}-0.203^{* * *} \\
(-5.95)\end{array}$ & $\begin{array}{c}-0.207^{* * * *} \\
(-4.19)\end{array}$ \\
\hline Disaster & $\begin{array}{c}0.0001 \\
(1.11)\end{array}$ & $\begin{array}{c}-0.0003^{* *} \\
(-2.21)\end{array}$ & $\begin{array}{l}0.001 \\
(1.42)\end{array}$ & $\begin{array}{c}0.001 * \\
(1.88)\end{array}$ & $\begin{array}{l}-0.0001 \\
(-0.57)\end{array}$ & $\begin{array}{l}-0.002 * \\
(-1.88)\end{array}$ & $\begin{array}{l}0.001 \\
(0.55)\end{array}$ & $\begin{array}{l}-0.0002 \\
(-0.23)\end{array}$ \\
\hline Small outreach MFIs & $\begin{array}{c}0.109^{* * *} \\
(3.07)\end{array}$ & $\begin{array}{c}0.258^{* * *} \\
(3.67)\end{array}$ & $\begin{array}{l}1.348^{*} \\
(1.98)\end{array}$ & $\begin{array}{l}0.787 * \\
(1.69)\end{array}$ & $\begin{array}{c}-0.263^{* * *} \\
(-2.90)\end{array}$ & $\begin{array}{l}-0.206 \\
(-1.04)\end{array}$ & $\begin{array}{l}0.648 \\
(1.25)\end{array}$ & $\begin{array}{l}-1.056^{*} \\
(-1.94)\end{array}$ \\
\hline Medium outreach MFIs & $\begin{array}{l}-0.006 \\
(-0.28)\end{array}$ & $\begin{array}{l}0.240 \\
(1.43)\end{array}$ & $\begin{array}{l}0.222 \\
(0.64)\end{array}$ & $\begin{array}{l}0.316 \\
(1.13)\end{array}$ & $\begin{array}{l}0.378 \\
(0.60)\end{array}$ & $\begin{array}{l}1.389 \\
(1.39)\end{array}$ & $\begin{array}{l}2.160 \\
(0.60)\end{array}$ & $\begin{array}{l}0.252 \\
(0.10)\end{array}$ \\
\hline Large outreach MFIs & $\begin{array}{l}-0.009 \\
(-0.43)\end{array}$ & $\begin{array}{l}0.079 \\
(0.73)\end{array}$ & $\begin{array}{l}0.202 \\
(0.67)\end{array}$ & $\begin{array}{l}0.146 \\
(0.60)\end{array}$ & $\begin{array}{l}0.121 \\
(1.05)\end{array}$ & $\begin{array}{l}0.569^{*} \\
(2.00)\end{array}$ & $\begin{array}{c}1.158^{* *} \\
(2.17)\end{array}$ & $\begin{array}{c}1.063^{* *} \\
(2.00)\end{array}$ \\
\hline $\begin{array}{c}\text { Disaster * Small } \\
\text { outreach MFIs }\end{array}$ & $\begin{array}{l}-0.005 \\
(-0.26)\end{array}$ & $\begin{array}{c}0.040^{* * *} \\
(2.73)\end{array}$ & $\begin{array}{l}-0.018 \\
(-0.76)\end{array}$ & $\begin{array}{l}-0.011 \\
(-0.41)\end{array}$ & $\begin{array}{l}0.004 \\
(0.04)\end{array}$ & $\begin{array}{l}-0.025 \\
(-0.13)\end{array}$ & $\begin{array}{l}-0.101 \\
(-0.31)\end{array}$ & $\begin{array}{c}0.150 \\
(-0.57)\end{array}$ \\
\hline $\begin{array}{l}\text { Disaster * Medium } \\
\text { outreach MFIs }\end{array}$ & $\begin{array}{l}0.003 \\
(1.09)\end{array}$ & $\begin{array}{l}0.030 * * \\
(2.40)\end{array}$ & $\begin{array}{c}0.038^{* * *} \\
(7.04)\end{array}$ & $\begin{array}{l}-0.010 \\
(-1.52)\end{array}$ & $\begin{array}{l}0.057 \\
(1.18)\end{array}$ & $\begin{array}{l}0.480 \text { ** } \\
(2.02)\end{array}$ & $\begin{array}{l}0.124 \\
(0.38)\end{array}$ & $\begin{array}{l}0.185 \\
(1.03)\end{array}$ \\
\hline $\begin{array}{l}\text { Disaster* Large } \\
\text { outreach MFIs }\end{array}$ & $\begin{array}{l}-0.004^{* * *} \\
(-4.32)\end{array}$ & $\begin{array}{c}0.010^{* * *} \\
(4.36)\end{array}$ & $\begin{array}{l}0.002 \\
(0.36)\end{array}$ & $\begin{array}{l}-0.002 \\
(-0.56)\end{array}$ & $\begin{array}{l}-0.002 \\
(-0.78)\end{array}$ & $0.018^{* *}$ & $\begin{array}{l}-0.009 \\
(-0.54)\end{array}$ & $\begin{array}{l}0.001 \\
(0.19)\end{array}$ \\
\hline $\begin{array}{l}\text { Observations } \\
\text { Countries }\end{array}$ & $\begin{array}{l}924 \\
84\end{array}$ & $\begin{array}{c}835 \\
77\end{array}$ & $\begin{array}{c}866 \\
82\end{array}$ & $\begin{array}{l}863 \\
82\end{array}$ & $\begin{array}{l}641 \\
65\end{array}$ & $\begin{array}{c}597 \\
60\end{array}$ & $\begin{array}{l}606 \\
64\end{array}$ & $\begin{array}{c}603 \\
64\end{array}$ \\
\hline
\end{tabular}

Results are generated using fixed effects method. All models include a constant, country, and year fixed effects. Models 5, 6, 7, and 8 are estimated including the control variables from Table 1. Errors are clustered at the country level. t-statistics are reported in parenthesis. ${ }^{*} p<0.10,{ }^{* *} p<0.05,{ }^{* * *} p<0.01$.

Table 7. Disasters, MFIs, and economic growth.

\begin{tabular}{|c|c|c|c|c|c|c|c|c|}
\hline & \multicolumn{8}{|c|}{ Dependent Variables } \\
\hline & (1) & (2) & (3) & (4) & (5) & (6) & (7) & (8) \\
\hline & $\begin{array}{c}\text { GDP } \\
\text { Growth }\end{array}$ & $\begin{array}{l}\text { Agricultural } \\
\text { Growth }\end{array}$ & $\begin{array}{l}\text { Industrial } \\
\text { Growth }\end{array}$ & $\begin{array}{l}\text { Service } \\
\text { Growth }\end{array}$ & $\begin{array}{c}\text { GDP } \\
\text { Growth }\end{array}$ & $\begin{array}{l}\text { Agricultural } \\
\text { Growth }\end{array}$ & $\begin{array}{l}\text { Industrial } \\
\text { Growth }\end{array}$ & $\begin{array}{l}\text { Service } \\
\text { Growth }\end{array}$ \\
\hline Initial output, in logs & $\begin{array}{c}0.197 * * * \\
(4.05)\end{array}$ & $\begin{array}{c}-0.239 * * * \\
(-5.95)\end{array}$ & $\begin{array}{c}-0.078^{* * *} \\
(-3.40)\end{array}$ & $\begin{array}{c}-0.043 * * * \\
(-2.79)\end{array}$ & $\begin{array}{l}0.005 \\
(0.10)\end{array}$ & $\begin{array}{c}-0.373^{* * *} \\
(-5.92)\end{array}$ & $\begin{array}{c}-0.200 * * * \\
(-6.44)\end{array}$ & $\begin{array}{c}-0.184 \text { *** } \\
(-4.85)\end{array}$ \\
\hline Disaster & $\begin{array}{c}0.0001 \\
(1.70)\end{array}$ & $\begin{array}{l}-0.0001 \\
(-0.76)\end{array}$ & $\begin{array}{c}0.001 * \\
(1.75)\end{array}$ & $\begin{array}{l}0.0005 \\
(2.26)\end{array}$ & $\begin{array}{c}0.0001 \\
(0.96)\end{array}$ & $\begin{array}{l}-0.0005 \\
(-1.20)\end{array}$ & $\begin{array}{l}0.001 \\
(1.32)\end{array}$ & $\begin{array}{c}0.0003 \\
(0.89)\end{array}$ \\
\hline MFIs (lagged) & $\begin{array}{l}-0.019 \\
(-0.91)\end{array}$ & $\begin{array}{l}0.125 \\
(0.85)\end{array}$ & $\begin{array}{l}0.209 \\
(0.58)\end{array}$ & $\begin{array}{l}0.178 \\
(0.61)\end{array}$ & $\begin{array}{l}0.008 \\
(0.07)\end{array}$ & $\begin{array}{c}0.529 * * \\
(2.41)\end{array}$ & $\begin{array}{c}0.893^{* *} \\
(2.20)\end{array}$ & $\begin{array}{l}0.581 \\
(1.61)\end{array}$ \\
\hline Disaster * MFIs (lagged) & $\begin{array}{c}-0.004^{* * *} \\
(-5.90)\end{array}$ & $\begin{array}{c}0.011^{* * *} \\
(4.26)\end{array}$ & $\begin{array}{l}0.001 \\
(0.19)\end{array}$ & $\begin{array}{l}-0.008 * \\
(-1.75)\end{array}$ & $\begin{array}{l}-0.002 \\
(-0.91)\end{array}$ & $\begin{array}{l}0.011 \\
(1.40)\end{array}$ & $\begin{array}{l}-0.014 \\
(-0.91)\end{array}$ & $\begin{array}{l}-0.001 \\
(-0.18)\end{array}$ \\
\hline Observations & 845 & 762 & 792 & 789 & 604 & 563 & 572 & 569 \\
\hline Countries & 82 & 75 & 80 & 80 & 64 & 59 & 63 & 63 \\
\hline
\end{tabular}

Results are generated using fixed effects method. All models include a constant, country, and year fixed effects. Models 5, 6, 7, and 8 are estimated including the control variables from Table 1. Errors are clustered at the country level. $\mathrm{t}$-statistics are reported in parenthesis. ${ }^{*} p<0.10,{ }^{* *} p<0.05,{ }^{* * *} p<0.01$.

Second, the growth models were re-estimated by including the specific disaster types (droughts, floods, earthquakes, and storms). Specific disasters have different impacts on aggregate growth and on specific sectors [4]. Moreover, we were also concerned with the heterogeneity of our sample in terms of MFIs. Put differently, the intervention of MFIs during a disaster event and in the aftermath may be significantly important in mitigating the effects of specific disasters and not other disasters. As one would expect, the results in Table 8 indicate varying effects of specific disasters on economic development. Floods imposed a disastrous effect on the growth of the agricultural sector, whereas earthquakes affected the industrial and service sectors. Some of these results seem not strange. For example, earthquakes are known to cause severe destruction to industrial infrastructure such as buildings and machinery [66], whereas floods majorly cause destructions to crops and other farm infrastructure $[67,68]$. In the interaction terms, the results support our main finding that accessibility to MFIs in the aftermath reduced the impact of natural disasters in the agricultural sector. However, this impact was more evident in cases of floods, storms, 
and earthquakes. The probable explanation for these results is that when disasters occur, farmers' output and farm infrastructure are usually severely destroyed, which may not be the case for the industry and service sectors, and because the majority of MFI clients, especially in developing countries, are farmers, it becomes logical for these MFIs to support their clients in reinvestment. The other results to note in Table 8 point to the impact of MFIs on earthquake events. It is shown that accessibility to MFIs also reduced the adverse effects of earthquakes on aggregate growth. This was not surprising because earthquakes can cause severe destruction within a short time period and thus, any intervention can easily be noticed.

Table 8. Specific disasters, MFIs, and economic growth.

\begin{tabular}{|c|c|c|c|c|c|c|c|c|}
\hline & \multicolumn{8}{|c|}{ Dependent Variables } \\
\hline & (1) & (2) & (3) & (4) & (5) & (6) & (7) & (8) \\
\hline & GDP & Agricultural & Industrial & Service & GDP & Agricultural & Industrial & Service \\
\hline & Growth & Growth & Growth & Growth & Growth & Growth & Growth & Growth \\
\hline \multirow[t]{2}{*}{ Initial output, in logs } & $0.187^{* * *}$ & $-0.241^{* * *}$ & $-0.064 * * *$ & $-0.036^{* *}$ & -0.005 & $-0.389 * * *$ & $-0.208^{* * *}$ & $-0.210^{* * *}$ \\
\hline & (3.79) & $(-8.14)$ & $(-3.55)$ & $(-2.25)$ & $(-0.09)$ & $(-6.59)$ & $(-5.91)$ & $(-4.12)$ \\
\hline \multirow[t]{2}{*}{ Droughts } & 0.0001 & -0.003 & -0.010 & -0.0003 & 0.00005 & -0.005 & -0.003 & -0.002 \\
\hline & $(0.50)$ & $(-1.21)$ & $(-0.49)$ & $(-0.20)$ & $(0.09)$ & $(-1.35)$ & $(-0.90)$ & $(-0.57)$ \\
\hline \multirow[t]{2}{*}{ Floods } & 0.0001 & $-0.0004^{* *}$ & $0.001 *$ & 0.001 & $0.0003^{* * *}$ & $-0.001^{* * *}$ & 0.0001 & -0.0001 \\
\hline & $(0.98)$ & $(-3.16)$ & $(1.92)$ & (1.42) & (3.02) & $(-3.30)$ & $(0.21)$ & $(-0.26)$ \\
\hline \multirow[t]{2}{*}{ Earthquakes } & -0.0002 & -0.001 & $-0.004^{* *}$ & $-0.003 *$ & -0.0003 & -0.001 & -0.001 & -0.002 \\
\hline & $(-0.53)$ & $(-1.50)$ & $(-2.00)$ & $(-1.75)$ & $(-0.73)$ & $(-1.43)$ & $(-0.27)$ & $(-0.71)$ \\
\hline \multirow[t]{2}{*}{ Storms } & 0.0001 & 0.00001 & 0.001 & 0.001 & -0.001 & -0.002 & $0.019 * *$ & 0.003 \\
\hline & $(0.59)$ & $(0.03)$ & $(0.97)$ & (1.17) & $(-0.99)$ & $(-1.66)$ & (2.59) & (0.58) \\
\hline \multirow[t]{2}{*}{ MFIs } & -0.016 & 0.076 & 0.174 & 0.139 & 0.053 & 0.282 & 0.924 ** & 0.580 \\
\hline & $(-0.58)$ & $(0.68)$ & $(0.48)$ & $(0.48)$ & $(0.45)$ & (1.10) & $(2.08)$ & (1.05) \\
\hline \multirow[t]{2}{*}{ Droughts * MFIs } & -0.005 & 0.093 & 0.050 & 0.033 & -0.001 & 0.156 & 0.103 & 0.056 \\
\hline & $(-0.72)$ & (1.53) & $(0.93)$ & $(0.84)$ & $(-0.08)$ & (1.49) & (1.03) & $(0.74)$ \\
\hline \multirow[t]{2}{*}{ Floods * MFIs } & -0.002 & $0.011^{* * *}$ & 0.001 & -0.002 & $-0.004^{* *}$ & $0.016^{* * *}$ & 0.006 & 0.006 \\
\hline & $(-0.83)$ & (3.39) & (0.18) & $(-0.36)$ & $(-2.36)$ & (3.21) & $(0.85)$ & $(0.83)$ \\
\hline \multirow[t]{2}{*}{ Earthquakes * MFIs } & $0.061^{* *}$ & $0.083^{* * *}$ & 0.276 & 0.217 & $0.049 * *$ & $0.077^{* *}$ & 0.114 & 0.156 \\
\hline & $(2.25)$ & (2.73) & (1.62) & (1.49) & $(2.62)$ & (2.01) & $(0.84)$ & $(1.14)$ \\
\hline \multirow[t]{2}{*}{ Storms * MFIs } & $-0.004^{* * *}$ & $0.014^{* * *}$ & 0.001 & $-0.008^{*}$ & -0.013 & $0.104^{* *}$ & -0.134 & -0.059 \\
\hline & $(-4.65)$ & $(9.61)$ & $(1.62)$ & $(-1.93)$ & $(-0.49)$ & $(2.19)$ & $(-1.16)$ & $(-0.53)$ \\
\hline Observations & 924 & 835 & 866 & 863 & 641 & 597 & 606 & 603 \\
\hline Countries & 84 & 77 & 82 & 82 & 65 & 60 & 64 & 64 \\
\hline
\end{tabular}

Results are generated using fixed effects method. All models include a constant, country, and year fixed effects. Models 5, 6, 7, and 8 are estimated including the control variables from Table 1 . Errors are clustered at the country level. t-statistics are reported in parenthesis. ${ }^{*} p<0.10,{ }^{* *} p<0.05,{ }^{* * *} p<0.01$.

The other robustness check considered the potential endogeneity that could have resulted from the potential reverse causation. First, even though we used GAME data for disasters, which is based on the exogenous intensity, a disaster count variable that reduces the influence of potential selection bias and also includes a set of control variables to account for the omitted variables bias, we may have failed to fully solve the endogeneity problem because some explanatory variables may have been endogenous with the growth variables. However, as argued earlier, during a disaster, some MFIs can find themselves at a point of liquidity crisis due to reduced individual savings and loan repayments coupled with increased savings withdrawals. As a result, if many clients are severely affected by a disaster, the MFI is more likely to fail to meet their financial demands, which causes accessibility to be endogenous. So, instead of ignoring this potential endogeneity problem, we followed Loayza et al. [4] and McDermott et al. [18] to re-estimate our main model using a dynamic panel data estimator that Arellano and Bover [69] and Blundell and Bond [70] designed to address this type of problem.

Focusing on the coefficients of the interaction term, the results in Table 9 seem to robustly support our main finding, which suggests that accessibility to MFIs reduced the impact of a natural disaster in the agricultural sector. 
Table 9. Disasters, MFIs, and economic growth.

\begin{tabular}{|c|c|c|c|c|c|c|c|c|}
\hline & \multicolumn{8}{|c|}{ Dependent Variables } \\
\hline & $\begin{array}{c}\text { (1) } \\
\text { GDP } \\
\text { Growth }\end{array}$ & $\begin{array}{c}\text { (2) } \\
\text { Agricultural } \\
\text { Growth }\end{array}$ & $\begin{array}{c}\text { (3) } \\
\text { Industrial } \\
\text { Growth }\end{array}$ & $\begin{array}{c}\text { (4) } \\
\text { Service } \\
\text { Growth }\end{array}$ & $\begin{array}{c}\text { (5) } \\
\text { GDP } \\
\text { Growth }\end{array}$ & $\begin{array}{l}\text { (6) } \\
\text { Agricultural } \\
\text { Growth }\end{array}$ & $\begin{array}{c}(7) \\
\text { Industrial } \\
\text { Growth }\end{array}$ & $\begin{array}{c}\text { (8) } \\
\text { Service } \\
\text { Growth }\end{array}$ \\
\hline Initial output, in logs & $\begin{array}{c}0.544^{* * *} \\
(3.81)\end{array}$ & $\begin{array}{l}0.011 \\
(0.27)\end{array}$ & $\begin{array}{l}0.081 * \\
(1.98)\end{array}$ & $\begin{array}{c}-0.026^{*} \\
(-1.73)\end{array}$ & $\begin{array}{l}-0.165 \\
(-1.10)\end{array}$ & $\begin{array}{l}-0.603 \\
(-1.37)\end{array}$ & $\begin{array}{c}-0.688^{* * *} \\
(-2.96)\end{array}$ & $\begin{array}{l}-0.194 \\
(-1.25)\end{array}$ \\
\hline Disaster & $\begin{array}{c}-0.0001 * * \\
(-2.08)\end{array}$ & $\begin{array}{l}-0.0001 \\
(-1.27)\end{array}$ & $\begin{array}{l}-0.001 \\
(-1.36)\end{array}$ & $\begin{array}{l}0.002 \\
(1.06)\end{array}$ & $\begin{array}{l}-0.0004 \\
(-0.81)\end{array}$ & $\begin{array}{l}-0.0005 \\
(-0.14)\end{array}$ & $\begin{array}{l}-0.002 \\
(-0.35)\end{array}$ & $\begin{array}{l}-0.001 \\
(-0.90)\end{array}$ \\
\hline MFIs & $\begin{array}{l}-0.032 \\
(-1.34)\end{array}$ & $\begin{array}{l}-0.118^{* *} \\
(-2.21)\end{array}$ & $\begin{array}{l}-0.938 \\
(-0.53)\end{array}$ & $\begin{array}{l}0.167 \\
(0.75)\end{array}$ & $\begin{array}{l}0.043 \\
(0.43)\end{array}$ & $\begin{array}{l}-0.418 \\
(-0.42)\end{array}$ & $\begin{array}{l}-3.722 \\
(-1.43)\end{array}$ & $\begin{array}{l}-1.790 \\
(-1.42)\end{array}$ \\
\hline Disaster * MFIs & $\begin{array}{c}0.00001 \\
(0.01)\end{array}$ & $\begin{array}{c}0.005^{* *} \\
(2.26)\end{array}$ & $\begin{array}{l}0.017 \\
(0.86)\end{array}$ & $\begin{array}{l}-0.096 \\
(-1.26)\end{array}$ & $\begin{array}{l}0.005 \\
(0.46)\end{array}$ & $\begin{array}{l}0.018 \\
(0.34)\end{array}$ & $\begin{array}{l}0.023 \\
(0.23)\end{array}$ & $\begin{array}{l}0.004 \\
(0.29)\end{array}$ \\
\hline Observations & 924 & 835 & 866 & 863 & 633 & 590 & 606 & 603 \\
\hline Countries & 84 & 77 & 82 & 82 & 65 & 60 & 64 & 64 \\
\hline No. of instruments & 55 & 55 & 45 & 54 & 38 & 38 & 45 & 49 \\
\hline $\begin{array}{l}\text { Arellano-Bond test } \\
\text { AR(2) }\end{array}$ & 0.313 & 0.159 & 0.133 & 0.237 & 0.200 & 0.425 & 0.439 & 0.110 \\
\hline Hansen test & 0.753 & 0.398 & 0.331 & 0.761 & 0.553 & 0.259 & 0.654 & 0.454 \\
\hline
\end{tabular}

Results are generated using xtabond 2 command in stata. Estimation technique is system-GMM. All models include a constant, country, and year fixed effects. Models 5, 6, 7, and 8 are estimated including the control variables from Table 1 . Errors are clustered at the country level. t-statistics are reported in parenthesis. ${ }^{*} p<0.10,{ }^{* *} p<0.05,{ }^{* * *} p<0.01$.

Finally, the results presented so far demonstrate the impact of disasters on economic growth and the associated effect of the intervention of MFIs in the short run. However, as argued by McDermott et al. [18], that the impact of the financial institutions' intervention may delay being manifested, there was still a possibility that the impact of the MFI intervention in the aftermath may be delayed in being manifested in the overall growth Secondly, the impact can also delay the industrial and service sectors, where reconstruction may take quite a long time. McDermott et al. [18] further maintained that countries with weak financial service development are likely to experience a persistent negative effect beyond the short run. To test for this, we conducted a robustness check by re-estimating our main model, including the disaster variable up to four lags (and the interaction term of the disaster variable with the MFI indicator). The results are reported in Table 10.

The results in columns 1,2,3,4, and 5 indicate that the impact of the intervention of MFIs in the aftermath only prevailed in the short run. Actually, it disappeared in the first lag even though it seemed to appear again in the second lag of the service sector (column 4) but still disappeared immediately. The possible explanations for this scenario could be that (1) if a disaster is persistent, MFIs may not have sufficient resources to withstand the persistent demand for credit and/or (2) the MFIs may develop a fear of possible default in case a disaster is persistent, given that they can directly affect the clients' repayment capacities. As a word of caution, our reader needs not confuse our finding with that in McDermott et al. [18], especially in the sample of developing countries. We confined our analysis on MFIs whereas McDermott et al. [18] confined their analysis to private credit, which is typically bigger than microcredit. In that case, it becomes logically possible for the positive impact of the intervention of private credit to have prevailed up to the eighth lag, as they demonstrated. 
Table 10. The long run effects of disasters and MFIs on economic growth.

\begin{tabular}{|c|c|c|c|c|c|c|c|c|c|}
\hline & & \multicolumn{8}{|c|}{ Dependent Variables } \\
\hline & & $\begin{array}{c}\text { (1) } \\
\text { GDP } \\
\text { Growth }\end{array}$ & $\begin{array}{l}\quad(2) \\
\text { Agricultural } \\
\text { Growth }\end{array}$ & $\begin{array}{c}\text { (3) } \\
\text { Industrial } \\
\text { Growth }\end{array}$ & $\begin{array}{c}\quad(4) \\
\text { Service } \\
\text { Growth }\end{array}$ & $\begin{array}{c}\text { (5) } \\
\text { GDP } \\
\text { Growth }\end{array}$ & $\begin{array}{l}\text { (6) } \\
\text { Agricultural } \\
\text { Growth }\end{array}$ & $\begin{array}{c}(7) \\
\text { Industrial } \\
\text { Growth }\end{array}$ & $\begin{array}{c}\quad(8) \\
\text { Service } \\
\text { Growth }\end{array}$ \\
\hline & $\begin{array}{l}\text { Initial output, } \\
\text { in logs }\end{array}$ & $\begin{array}{l}0.097 \\
(1.23) \\
\end{array}$ & $\begin{array}{c}-0.391^{* * *} \\
(-6.68)\end{array}$ & $\begin{array}{c}-0.142^{* * *} \\
(-5.48)\end{array}$ & $\begin{array}{c}-0.123 * * * \\
(-6.80)\end{array}$ & $\begin{array}{l}-0.083 \\
(-1.23) \\
\end{array}$ & $\begin{array}{c}-0.580^{* * *} \\
(-8.98) \\
\end{array}$ & $\begin{array}{c}-0.236^{* * *} \\
(-7.04)\end{array}$ & $\begin{array}{c}-0.247^{* * *} \\
(-5.14)\end{array}$ \\
\hline$t=0$ & $\begin{array}{c}\text { Disaster } \\
\text { MFIs } \\
\text { Disaster * MFIs }\end{array}$ & $\begin{array}{c}0.0001 \\
(0.58) \\
0.231^{* * *} \\
(2.71) \\
0.006^{* * *} \\
(3.14) \\
\end{array}$ & $\begin{array}{c}0.0002 \\
(1.11) \\
0.018 \\
(0.16) \\
0.008^{* *} \\
(2.31)\end{array}$ & $\begin{array}{c}0.0002 \\
(0.22) \\
0.876^{*} \\
(1.89) \\
0.022^{* *} \\
(2.04)\end{array}$ & $\begin{array}{c}-0.00003 \\
(-0.08) \\
0.266 \\
(0.81) \\
0.017^{* *} \\
(2.34) \\
\end{array}$ & $\begin{array}{c}-0.0003 \\
(-0.89) \\
0.524^{* * *} \\
(2.68) \\
0.014^{* * *} \\
(2.77)\end{array}$ & $\begin{array}{c}0.0001 \\
(0.11) \\
-0.156 \\
(-0.46) \\
0.002 \\
(0.16) \\
\end{array}$ & $\begin{array}{c}0.004 \\
(1.04) \\
1.817 \\
(1.51) \\
-0.025 \\
(-0.67) \\
\end{array}$ & $\begin{array}{c}0.0005 \\
(0.29) \\
0.976 \\
(0.77) \\
-0.006 \\
(-0.31) \\
\end{array}$ \\
\hline $\mathrm{t}=1$ & $\begin{array}{c}\text { Disaster } \\
\text { MFIs } \\
\text { Disaster * MFIs }\end{array}$ & $\begin{array}{c}0.0002 \\
(1.18) \\
-0.320 * * \\
(-2.28) \\
-0.007 \\
(-1.55)\end{array}$ & $\begin{array}{c}0.0002 \\
(0.98) \\
0.333 \\
(1.17) \\
-0.008 \\
(-1.13) \\
\end{array}$ & $\begin{array}{c}0.001 \\
(2.04) \\
-1.176 \\
(-1.88) \\
-0.026 * \\
(-1.72)\end{array}$ & $\begin{array}{c}0.001 \text { * } \\
(1.99) \\
0.029 \\
(0.06) \\
-0.031 \text { ** } \\
(-2.44)\end{array}$ & $\begin{array}{c}0.001 \\
(1.40) \\
-0.231 \\
(-0.66) \\
-0.005 \\
(-0.47) \\
\end{array}$ & $\begin{array}{c}0.0001 \\
(0.05) \\
1.175^{* *} \\
(2.27) \\
0.008 \\
(0.21)\end{array}$ & $\begin{array}{c}0.006 \\
(1.45) \\
-0.147 \\
(-0.10) \\
-0.098 \\
(-1.29) \\
\end{array}$ & $\begin{array}{c}0.001 \\
(0.64) \\
0.847 \\
(0.59) \\
-0.015 \\
(-0.34) \\
\end{array}$ \\
\hline$t=2$ & $\begin{array}{c}\text { Disaster } \\
\text { MFIs } \\
\text { Disaster * MFIs }\end{array}$ & $\begin{array}{l}0.0002 \\
(1.42) \\
0.015 \\
(0.11) \\
0.004 \\
(1.05) \\
\end{array}$ & $\begin{array}{c}0.00003 \\
(0.04) \\
-0.434 \\
(-1.62) \\
0.008 \\
(1.03) \\
\end{array}$ & $\begin{array}{c}-0.00002 \\
(-0.05) \\
0.702 * \\
(1.90) \\
0.013 \\
(1.19)\end{array}$ & $\begin{array}{c}-0.0002 \\
(-0.56) \\
-0.184 \\
(-0.52) \\
0.017^{* *} \\
(2.12)\end{array}$ & $\begin{array}{c}0.003 \\
(0.55) \\
-0.115 \\
(-0.44) \\
0.002 \\
(0.19) \\
\end{array}$ & $\begin{array}{c}-0.001 \\
(-0.58) \\
-0.234 \\
(-0.35) \\
0.024 \\
(1.06)\end{array}$ & $\begin{array}{c}0.001 \\
(0.21) \\
1.634 * * \\
(2.22) \\
0.014 \\
(0.28) \\
\end{array}$ & $\begin{array}{c}-0.003 \\
(-1.25) \\
0.687 \\
(0.89) \\
0.069 \\
(1.67) \\
\end{array}$ \\
\hline$t=3$ & $\begin{array}{c}\text { Disaster } \\
\text { MFIs } \\
\text { Disaster * MFIs }\end{array}$ & $\begin{array}{c}0.0001 \\
(1.02) \\
-0.006 \\
(-0.07) \\
0.005 \\
(1.47)\end{array}$ & $\begin{array}{c}0.0001 \\
(0.38) \\
-0.301 \\
(-1.63) \\
0.011 \\
(1.09)\end{array}$ & $\begin{array}{c}0.001^{* * *} \\
(3.13) \\
-1.624^{* * *} \\
(-3.91) \\
-0.001 \\
(-0.09)\end{array}$ & $\begin{array}{c}0.001 \\
(1.37) \\
-1.060 * * * \\
(-2.97) \\
0.007 \\
(0.47)\end{array}$ & $\begin{array}{c}0.0003 \\
(1.00) \\
-0.170 \\
(-1.21) \\
0.010 \\
(1.11)\end{array}$ & $\begin{array}{c}0.001 \\
(0.74) \\
0.181 \\
(0.40) \\
-0.011 \\
(-0.36)\end{array}$ & $\begin{array}{c}0.003 \\
(1.29) \\
-1.139 * * \\
(-2.02) \\
-0.018 \\
(-0.41)\end{array}$ & $\begin{array}{c}0.001 \\
(1.02) \\
-0.888 \\
(-1.55) \\
-0.036 \\
(-1.48)\end{array}$ \\
\hline $\mathrm{t}=4$ & $\begin{array}{c}\text { Disaster } \\
\text { MFIs } \\
\text { Disaster * MFIs }\end{array}$ & $\begin{array}{c}0.0001 \\
(0.76) \\
0.090 \\
(0.59) \\
-0.016 \\
(-4.53) \\
\end{array}$ & $\begin{array}{c}0.0003 \\
(0.97) \\
1.012^{* * *} \\
(5.28) \\
-0.005 \\
(-0.38) \\
\end{array}$ & $\begin{array}{c}0.0002 \\
(1.08) \\
2.554^{* * *} \\
(6.44) \\
-0.019 \\
(-0.92)\end{array}$ & $\begin{array}{c}0.0003 \\
(0.89) \\
2.219^{* * *} \\
(7.88) \\
-0.017 \\
(-0.91) \\
\end{array}$ & $\begin{array}{c}0.001 \text { ** } \\
(2.16) \\
0.032 \\
(0.27) \\
-0.017 \\
(-1.56)\end{array}$ & $\begin{array}{c}-0.0001 \\
(-0.16) \\
-0.526 \\
(-0.99) \\
0.019 \\
(0.69)\end{array}$ & $\begin{array}{c}-0.002 \\
(-0.94) \\
-0.920 * \\
(-1.73) \\
0.105 \\
(0.94)\end{array}$ & $\begin{array}{c}-0.001 \\
(-0.78) \\
-0.751 \\
(-1.37) \\
0.033 \\
(0.66)\end{array}$ \\
\hline & $\begin{array}{c}\text { Observations } \\
\text { Countries }\end{array}$ & $\begin{array}{c}592 \\
78\end{array}$ & $\begin{array}{c}534 \\
69\end{array}$ & $\begin{array}{c}558 \\
76\end{array}$ & $\begin{array}{c}555 \\
76\end{array}$ & $\begin{array}{c}448 \\
59\end{array}$ & $\begin{array}{c}418 \\
54\end{array}$ & $\begin{array}{c}428 \\
58\end{array}$ & $\begin{array}{c}425 \\
58\end{array}$ \\
\hline
\end{tabular}

Results are generated using fixed effects estimation technique. All models include a constant, country, and year fixed effects. Models 5, 6, 7, and 8 are estimated including the control variables from Table 1 . t-statistics are reported in parenthesis. ${ }^{*} p<0.10,{ }^{* *} p<0.05,{ }^{* * *} p<0.01$.

\section{Conclusions}

In this study, we explored whether microfinance institutions (MFIs) are able to mitigate the adverse macroeconomic consequences of natural disasters. The provision of capital immediately following a natural event is recognized as one of the necessary conditions for a fast economic recovery. However, one concern is that the majority of natural disasters occur in developing countries where households and the private sector have only limited access to the formal banking system. As an alternative, MFIs may fill up this gap in providing liquidity in the form of microcredit. There exists vast literature on the potential micro effects of credit constraints, arguing that access to MFI credit can ease the adverse economic effects caused by a natural disaster. However, the evidence so far is mainly based on micro studies of a single event. Based on these case studies, it is difficult to draw general conclusions since natural disasters differ in their economic effect, the activities employed 
by MFIs are likely to vary between MFIs, and the socio-economic context of the disaster location differs.

Using an unbalanced panel considering more than 80 developing countries and emerging economies and after extensive testing of the robustness, we can conclude that natural disasters have an adverse effect on the macroeconomic performance primarily through their effect on the agricultural sector. However, access to lending facilities from MFIs mitigates a large part of this negative effect. For this reason, recapitalizing MFIs after calamities may be crucial. The extent to which MFIs are able to mitigate these effects depends to a great extent on their nature, i.e., their organizational structure, profitability, legal status, age, and the number of clients they serve.

One limitation regarding this study is that the availability and quality of MFI data might influence the results through a sample selection issue. Although we considered almost all countries identified by the UNDP as developing or emerging market countries, there is still a possibility that there is a sample selection effect of the considered MFIs within a country. This again can be an interesting starting point for future research.

Author Contributions: Conceptualization, J.K. and J.S.; Formal analysis, J.S.; Methodology, J.S.; Supervision, J.K.; Writing—original draft, J.S.; Writing—review \& editing, J.K. Both authors have read and agreed to the published version of the manuscript.

Funding: This research was funded by the Dutch Organization for Scientific Research, grant number 2100888800 .

Institutional Review Board Statement: Not applicable.

Informed Consent Statement: Not applicable.

Data Availability Statement: The data used in this study are available from the corresponding author on reasonable request.

Conflicts of Interest: The authors declare no conflict of interest.

Appendix A. Summary Statistics

\begin{tabular}{cccccc}
\hline Variables & Obs & Mean & Std. Dev & Min & Max \\
\hline Growth in & & & & & \\
GDP & 1349 & 0.047 & 0.054 & -0.281 & 0.890 \\
Agricultural sector (pc) & 1144 & 0.012 & 0.080 & -0.606 & 0.571 \\
Industrial sector(pc) & 1191 & 0.074 & 0.193 & -1.686 & 1.822 \\
Service sector(pc) & 1188 & 0.077 & 0.169 & -1.564 & 0.992 \\
Control variables & & & & & \\
Education attainment(in logs) & 1104 & 3.089 & 0.832 & 0.742 & 4.428 \\
Financial depth (in logs) & 1315 & 2.939 & 0.925 & -0.382 & 5.110 \\
Government burden (in logs) & 1286 & 25.175 & 2.718 & 16.213 & 34.061 \\
Inflation (in logs) & 1254 & 0.125 & 0.246 & -0.142 & 3.748 \\
trade openness (in logs) & 1329 & 4.134 & 0.591 & -1.171 & 5.395 \\
Growth rate of terms of trade & 1142 & 0.007 & 0.109 & -0.975 & 0.518 \\
Number of active borrowers & 932 & $925,935.6$ & $5,403,037$ & 24.000 & $88,000,000$ \\
Population & 1376 & $55,800,000$ & $179,000,000$ & 465,895 & $1,300,000,000$ \\
Number of active & 932 & 0.017 & 0.048 & 0.00000057 & 0.733 \\
borrowers/population & & & & & \\
Diamond dummy & 930 & 0.380 & 0.341 & 0.000 & 1.000 \\
Land size (sq KM) & 1376 & $764,587.6$ & $1,428,676$ & 1861 & $9,400,000$ \\
Count measure for & & & & & 14.667 \\
All disasters & 1360 & 1.511 & 2.416 & 0.000 & 12.000 \\
Droughts & 1360 & 0.743 & 2.088 & 0.000 & 6.333 \\
Floods & 1360 & 0.265 & 0.897 & 0.000 & 2.000 \\
Earthquakes & 1360 & 0.321 & 0.815 & 0.000 & \\
Storms & 1360 & 0.182 & 0.372 & 0.000 & \\
\hline
\end{tabular}


Appendix B. Control Variables

\begin{tabular}{ccc}
\hline Variable & Description & Data Source \\
\hline Education attainment & $\begin{array}{c}\text { Gross secondary school } \\
\text { enrolment rate, in logs }\end{array}$ & $\begin{array}{c}\text { World Development } \\
\text { Indicators (2014) } \\
\text { World Development } \\
\text { Financial depth }\end{array}$ \\
Private credit/GDP, in logs & Indicators (2014) \\
Government burden & Government final & Indicators (2014) \\
Inflation & consumption/GDP, in logs & World Development \\
& $100+\%$ growth rate in CPI & Indicators (2014) \\
Trade openness & Exports + Imports/GDP, in logs & World Development \\
& Indicators (2014) \\
Terms of trade & Log difference of the net barter & World Development \\
& terms of trade index. & Indicators (2014) \\
\hline
\end{tabular}

\section{Appendix C. Sample of Countries}

\begin{tabular}{|c|c|c|}
\hline Afghanistan & Guinea & Paraguay \\
\hline Albania & Guinea-Bissau & Peru \\
\hline Angola & Guyana & Philippines \\
\hline Argentina & Haiti & Poland \\
\hline Armenia & Honduras & Romania \\
\hline Azerbaijan & India & Rwanda \\
\hline Bangladesh & Indonesia & Senegal \\
\hline Benin & Jamaica & Serbia \\
\hline Bolivia & Jordan & Sierra Leone \\
\hline Bosnia and Herzegovina & Kazakhstan & South Africa \\
\hline Brazil & Kenya & Sri Lanka \\
\hline Burkina Faso & Laos & Sudan \\
\hline Burundi & Macedonia & Swaziland \\
\hline Cambodia & Madagascar & Syria \\
\hline Chad & Malawi & Tajikistan \\
\hline Chile & Malaysia & Tanzania \\
\hline China & Mexico & Thailand \\
\hline Colombia & Moldova & Togo \\
\hline Comoros & Mongolia & Turkey \\
\hline $\begin{array}{c}\text { Democratic Republic of } \\
\text { Congo }\end{array}$ & Morocco & Uganda \\
\hline Costa Rica & Mozambique & Ukraine \\
\hline Dominican Republic & Myanmar & Uruguay \\
\hline Ecuador & Namibia & Uzbekistan \\
\hline Egypt & Nepal & Venezuela \\
\hline El Salvador & Nicaragua & Vietnam \\
\hline Ethiopia & Niger & Yemen \\
\hline Georgia & Nigeria & Zambia \\
\hline Ghana & Pakistan & Zimbabwe \\
\hline Guatemala & Papua New Guinea & \\
\hline
\end{tabular}

\section{References}

1. Intergovernmental Panel on Climate Change (IPCC). Climate Change: The Scientific Basis. Contribution of Working Group I to the Fourth Assessment Report of the Inter-Governmental Panel on Climate Change; Solomon, S., Qin, D., Manning, M., Chen, Z., Marquis, M., Averyt, K.B., Tignor, M., Miller, H., Eds.; Cambridge University Press: New York, NY, USA, 2007.

2. EM-DAT: The OFDA/CRED International Disaster Database; Université Catholique de Louvain: Brussels, Belgium, 2015; Available online: www.emdat.be/database (accessed on 15 May 2015).

3. Raddatz, C.E. The wrath of God: Macroeconomic Costs of Natural Disasters; World Bank Policy Research Working Paper Series; The World Bank Group: Washington, WA, USA, 2009.

4. Loayza, N.V.; Olaberría, E.; Rigolini, J.; Christiaensen, L. Natural Disasters and Growth: Going Beyond the Averages. World Dev. 2012, 40, 1317-1336. [CrossRef] 
5. Fomby, T.; Ikeda, Y.; Loayza, N. The growth aftermath of natural disasters. J. Appl. Econ. 2011, 28, 412-434. [CrossRef]

6. Noy, I. The macroeconomic consequences of disasters. J. Dev. Econ. 2009, 88, 221-231. [CrossRef]

7. Skidmore, M.; Toya, H. Do natural disasters promote long-run growth? Econ. Inq. 2002, 40, 664-687. [CrossRef]

8. Cavallo, E.; Galiani, S.; Noy, I.; Pantano, J. Catastrophic natural disasters and economic growth. Rev. Econ. Stat. 2013, 95, 1549-1561. [CrossRef]

9. Mechler, R. Macroeconomic Impacts of Natural Disasters; The World Bank Group: Washington, WA, USA, 2003.

10. Narayan, P.K. Macroeconomic impact of natural disasters on a small island economy: evidence from a CGE model. Appl. Econ. Lett. 2003, 10, 721-723. [CrossRef]

11. Rasmussen, T.N. Macroeconomic Implications of Natural Disasters in the Caribbean; International Monetary Fund: Washington, WA, USA, 2004.

12. Strömberg, D. Natural Disasters, Economic Development, and Humanitarian Aid. J. Econ. Perspect. 2007, 21, 199-222. [CrossRef]

13. Klomp, J. Economic development and natural disasters: A satellite data analysis. Glob. Environ. Chang. 2016, 36, 67-88. [CrossRef]

14. Klomp, J.; Valckx, K. Natural disasters and economic growth: A meta-analysis. Glob. Environ. Chang. 2014, 26, 183-195. [CrossRef]

15. Felbermayr, G.; Gröschl, J. Naturally negative: The growth effects of natural disasters. J. Dev. Econ. 2014, 111, 92-106. [CrossRef]

16. Melecky, M.; Raddatz, C. Fiscal responses after catastrophes and the enabling role of financial development. World Bank Econ. Rev. 2015, 29, 129-149. [CrossRef]

17. Von Peter, G.; Von Dahlen, S.; Saxena, S.C. Unmitigated Disasters? New Evidence on the Macroeconomic Cost of Natural Catastrophes; BIS Working Paper No 394; Bank for International Settlements: Basel, Switzerland, 2012.

18. McDermott, T.K.; Barry, F.; Tol, R.S. Disasters and development: natural disasters, credit constraints, and economic growth Oxf. Econ. Pap. 2014, 66, 750-773. [CrossRef]

19. Chaia, A.; Dalal, A.; Goland, T.; Gonzalez, M.J.; Morduch, J.; Schiff, R. 2 Half the World Is Unbanked. In Banking the World: Empirical Foundations of Financial Inclusion; MIT Press: Cambridge, MA, USA, 2013; p. 19.

20. Armendáriz, B.; Morduch, J. The Economics of Microfinance; MIT Press: Cambridge, MA, USA, 2005.

21. Collier, B.; Miranda, M.J.; Skees, J. Natural Disasters and Credit Supply Shocks in Developing and Emerging Economies. Ph.D. Thesis, University of Kentucky, Lexington, KY, USA, 2013.

22. Krauss, N.; Walter, I. Can microfinance reduce portfolio volatility? Econ. Dev. Cult. Chang. 2009, 58, 85-110. [CrossRef]

23. Gitter, S.R.; Barham, B.L. Credit, natural disasters, coffee, and educational attainment in rural Honduras. World Dev. 2007, 35, 498-511. [CrossRef]

24. Khandker, S.R. Coping with flood: role of institutions in Bangladesh. Agric. Econ. 2007, 36, 169-180. [CrossRef]

25. Shoji, M. Does contingent repayment in microfinance help the poor during natural disasters? J. Dev. Stud. 2010, 46, 191-210. [CrossRef]

26. Becchetti, L.; Castriota, S. Does microfinance work as a recovery tool after disasters? Evidence from the 2004 tsunami. World Dev. 2011, 39, 898-912. [CrossRef]

27. Altay, N.; Ramirez, A. Impact of disasters on firms in different sectors: implications for supply chains. J. Supply Chain Manag. 2010, 46, 59-80. [CrossRef]

28. Brown, S.; Palliyaguru, R.; Amaratunga, D. Managing disaster risks through quality infrastructure and vice versa: Post-disaster infrastructure reconstruction practices. Struct. Surv. 2008, 26, 426-434.

29. Ofori, G. Construction Industry Development for Disaster Prevention and Response. In Proceedings of the i-Rec International Conference on Post-Disaster reconstruction: Planning for reconstruction, Montreal, QC, Canada, 24-25 May 2002.

30. Miamidian, E.; Arnold, M.; Jacquand, M.; Burritt, K. Surviving Disasters and Supporting Recovery: A Guidebook for Microfinance Institutions; The World Bank: Washington, WA, USA, 2005.

31. Klomp, J. Do natural catastrophes shake microfinance institutions? Using a new measure of MFI risk. Int. J. Disaster Risk Reduct. 2018, 27, 380-390. [CrossRef]

32. Batrancea, I.; Malar Kumaran, R.; Larissa, B.; Anca, N.; Lucian, G.; Gheorghe, F.; Mircea-Iosif, R. A panel data analysis on sustainable economic growth in India, Brazil, and Romania. J. Risk Financ. Manag. 2020, 13, 170.

33. Batrancea, I.; Mozi, R.M.; Lucian, G.; Gheorghe, F.; Horia, T.; Ioan, B.; Mircea-Iosif, R. An empirical investigation on determinants of sustainable economic growth. Lessons from Central and Eastern European Countries. J. Risk Financ. Manag. 2020, 13, 146.

34. Batrancea, L.; Maran, R.M.; Ioan, B.; Anca, N.; Mircea-Iosif, R.; Horia, T.; Dan, M.I. Adjusted net savings of CEE and Baltic nations in the context of sustainable economic growth: A panel data analysis. J. Risk Financ. Manag. 2020, 13, 234.

35. World Bank. World Development Indicators 2014. Available online: https://www.databank.worldbank.org (accessed on 5 November 2014).

36. Mix Market. Microfinance Data 2012. Available online: https://www.themix.org/mix-market (accessed on 12 September 2012).

37. Collier, B.; Skees, J. Increasing the resilience of financial intermediaries through portfolio-level insurance against natural disasters. Nat. Hazards 2012, 64, 55-72. [CrossRef]

38. Gálvez-Sánchez, F.J.; Lara-Rubio, J.; Verdú-Jóver, A.J.; Meseguer-Sánchez, V. Research Advances on Financial Inclusion: A Bibliometric Analysis. Sustainability 2021, 13, 3156. [CrossRef]

39. Berg, G.; Schrader, J. Access to credit, natural disasters, and relationship lending. J. Financ. Intermediation 2012, 21, 549-568. [CrossRef]

40. Anand Kumar, T.; Newport, J.K. Role of microfinance in disaster mitigation. Disaster Prev. Manag. Int. J. 2005, 14, 176-182. [CrossRef] 
41. Pantoja, E. Microfinance and Disaster Risk Management: Experiences and Lessons Learned; The World Bank: Washington, WA, USA, 2002.

42. Del Ninno, C.; Dorosh, P.A.; Smith, L.C. Public policy, markets and household coping strategies in Bangladesh: Avoiding a food security crisis following the 1998 floods. World Dev. 2003, 31, 1221-1238. [CrossRef]

43. Hoque, M.; Itohara, Y. Participation and decision making role of rural women in economic activities: A comparative study for members and non-members of the micro-credit organizations in Bangladesh. J. Soc. Sci. 2008, 4, 229-236.

44. Neumayer, E.; Plümper, T.; Barthel, F. The political economy of natural disaster damage. Glob. Environ. Chang. 2014, 24, 8-19. [CrossRef]

45. Gassebner, M.; Keck, A.; Teh, R. Shaken, not stirred: the impact of disasters on international trade. Rev. Int. Econ. 2010, 18, 351-368. [CrossRef]

46. Pelling, M.; Özerdem, A.; Barakat, S. The macro-economic impact of disasters. Prog. Dev. Stud. 2002, 2, 283-305. [CrossRef]

47. Cull, R.; Demirgüç-Kunt, A.; Morduch, J. Microfinance Meets the Market Moving Beyond Storytelling: Emerging Research in Microfinance; Emerald Group Publishing Limited: Bingley, UK, 2009; pp. 1-30.

48. Gonzalez, A. Resilience of microfinance institutions to national macroeconomic events: An econometric analysis of MFI asset quality. SSRN Electron. J. 2007. [CrossRef]

49. Mersland, R.; Strøm, R. Performance and governance in microfinance institutions. J. Bank. Financ. 2009, 33, 662-669. [CrossRef]

50. Mersland, R.; Strøm, R. Microfinance mission drift? World Dev. 2010, 38, 28-36. [CrossRef]

51. Hermes, N.; Lensink, R.; Meesters, A. Outreach and efficiency of microfinance institutions. World Dev. 2011, 39, 938-948. [CrossRef]

52. Galema, R.; Lensink, R.; Spierdijk, L. International diversification and microfinance. J. Int. Money Financ. 2011, 30, 507-515. [CrossRef]

53. Beisland, L.A.; Mersland, R. An analysis of the drivers of microfinance rating assessments. Nonprofit Volunt. Sect. Q. 2012, 41, 213-231. [CrossRef]

54. Mersland, R.; Randøy, T.; Strøm, R. The impact of international influence on micro banks'performance: A global survey. Int. Bus. Rev. 2011, 20, 163-176. [CrossRef]

55. Gutiérrez-Nieto, B.; Serrano-Cinca, C.; Molinero, C.M. Social efficiency in microfinance institutions. J. Oper. Res. Soc. 2009, 60, 104-119. [CrossRef]

56. Tchakoute-Tchuigoua, H. Is there a difference in performance by the legal status of microfinance institutions? Q. Rev. Econ. Financ. 2010, 50, 436-442. [CrossRef]

57. Hartarska, V. Governance and performance of microfinance institutions in Central and Eastern Europe and the newly independent states. World Dev. 2005, 33, 1627-1643. [CrossRef]

58. Albala-Bertrand, J.M. Natural disaster situations and growth: A macroeconomic model for sudden disaster impacts. World Dev. 1993, 21, 1417-1434. [CrossRef]

59. Kahn, M.E. The death toll from natural disasters: the role of income, geography, and institutions. Rev. Econ. Stat. 2005, 87, 271-284. [CrossRef]

60. Klomp, J. Financial fragility and natural disasters: An empirical analysis. J. Financ. Stab. 2014, 13, 180-192. [CrossRef]

61. Shoji, M. COE Discussion Paper F-138, Kyoto. 2006. Available online: http://www.computer-services.e.u-tokyo.ac.jp/p/cemano/ research/DP/documents/coe-f-138.pdf (accessed on 29 April 2021).

62. Skees, J.R.; Collier, B. Climate Change_Risk Management Solutions for Developing Economies: A Portfolio Approach; Global Centre on Disaster Risk and Poverty: Lexington, KY, USA, 2012.

63. Anand Kumar, T.; Newport, J.K. Institutional preparedness and sustainability of micro finance institutions during post disaster scenario. Disaster Prev. Manag. Int. J. 2007, 16, 21-32. [CrossRef]

64. Barnett, B.J.; Mahul, O. Weather index insurance for agriculture and rural areas in lower-income countries. Am. J. Agric. Econ. 2007, 89, 1241-1247. [CrossRef]

65. Freeman, P.K.; Keen, M.; Mani, M. Being Prepared. Financ. Dev. 2003, 40, 42-45.

66. Durukal, E.; Erdik, M.; Sanli, B. Damage to and Vulnerability of Industry in Earthquakes in Turkey. Geophys. Res. Abstr. 2006, 8, 10041.

67. Devereux, S. The impact of droughts and floods on food security and policy options to alleviate negative effects. Agric. Econ. 2007, 37, 47-58. [CrossRef]

68. Posthumus, H.; Morris, J.; Hess, T.; Neville, D.; Phillips, E.; Baylis, A. Impacts of the summer 2007 floods on agriculture in England. J. Flood Risk Manag. 2009, 2, 182-189. [CrossRef]

69. Arellano, M.; Bover, O. Another look at the instrumental variable estimation of error-components models. J. Econom. 1995, 68, 29-51. [CrossRef]

70. Blundell, R.; Bond, S. Initial conditions and moment restrictions in dynamic panel data models. J. Econom. 1998, 87, 115-143. [CrossRef] 